\title{
State Responsibility to Investigate and Prosecute Grivave Human Rights Violations in International Law
}

\author{
Naomi Roht-Arriaza
}

\section{TABBLE OF CONTENTS}

Introduction

I. State Denial of Responsibility for Human Rights

Violations

A. The Nature of Disappearances and Death Squads .... 453

B. The Problem of Successor Governments ............ 458

II. Treaty-Based Sources of an Obligation to Investigate and Prosecute

A. Criminal Law Provisions ...................... 462

B. "Ensure and Respect" and the Velasquez Case........ 467

C. Hunian Rights Treaties and the Right to a Remedy for Human Rights Violations ......................... 474

1. Right to a Remedy in International Instruments ... 474

2. The Scope of Remedy Required by Human Rights Instruments .............................. 479

D. Is the Treaty-Based Obligation Derogable? Amnesties Under International Law ...................... 483

III. The Obligation to Investigate and Prosecute as Customary Law ...................................... 489

A. Treaty Provisions as the Basis of the Customary Norm.................................. 490

B. The Practice of States ........................ 492

1. Prosecutions of Violators.................. 493

2. Provisions of Domestic Law................. 494

3. Verbal Statements of Governmental Representatives ........................ 496

4. Resolutions and Declarations of International Organizations.......................... 498

C. Prior Customary Law: State Responsibility for Injuries to Aliens and the Obligation to Investigate and Prosecute ................................ 500

D. Necessity as an Exception to the State Obligation .... 505 
IV. Policy Implications of an International Obligation to

Investigate and Prosecute .................... 505

A. Implications for Governments Where Abuses Continue:

Shifting the Burden of Proof................... 506

B. Inplications for Deinocratic Governments Replacing

Repressive Regimes.......................... 508

Conclusion 


\title{
State Responsibility to Investigate and Prosecute Grave Human Rights Violations in International Law
}

\author{
Naomi Roht-Arriaza $\uparrow$
}

Most of the world rejoices when a new government takes the reins of power from a repressive regime. For the families and friends of those killed or "disappeared" by death squads, however, the new regime may bring no relief. Without an affirmative obligation to investigate and prosecute past human rights abuses, governments may officially forget past misdeeds in an attempt to promote national unity or to avoid confrontations with the military. This Comment demonstrates that in fact an obligation to investigate and prosecute certain grave human rights violations exists in both conventional and customary international law. The author argues that governments should recognize the obligation, since it reflects an emerging consensus in international law. The Comment examines the policy implications of adopting this affirmative obligation, and concludes that it would well serve the cause of human rights and democracy.

Time passing

Is it oblivion

Or only the faint memory

Of an unfinished story?

- Alaide Foppa, Guatemalan poet, feminist, teacher, and mother

Disappeared December 19, 1980

To her memory and that of all the others

\section{INTRODUCTION}

During the last twenty years, repressive governments have sought to hide their responsibility for killing or torturing opponents, through the use of "death squad" murders and disappearances. ${ }^{1}$ In cases of murder by death squads, these governments deny any responsibility by arguing that the acts were performed by individuals not affiliated with the regime.

$\dagger$ B.A., 1978, University of California at Berkeley. J.D. candidate 1990, Boalt Hall School of Law, University of California, Berkeley. The author wishes to thank Professor C. Patty Blum, Professor David Caron, Professor Frank Newman, Sandra Colliver, Chris Conner and Melissa Thomas for their help in preparing this Comment.

1. See infra notes 9-29 and accompanying text for descriptions of these practices. 
In cases of disappearance, the governments often claim that there is no proof that any crime has occurred at all.

Some of these repressive governments have been replaced by regimes pledging more respect for human rights. But when relatives of victims and the human rights commumity have pressed for a full investigation of past violations, for sanctions, and for reparation for the victims, successor governments have reacted by denying any responsibility to redress past violations. They have argued that im order to protect national unity it is imperative to forget the acts committed by the prior regime and grant amnesty to the alleged perpetrators.

This Comment argues for the recoguition of an affirmative international law obligation on states to investigate disappearances, death squad killings, and other grave human rights violations-attributable to both their own and to predecessor governments-and to take action against the responsible parties. ${ }^{2}$ The Comment explores the sources and extent of an affirmative obhigation to imvestigate and prosecute, focusing on examples from Latm America. While disappearances, death squads, and the problem of successor regimes are global phenomena, Latin America has been the scene of widespread use of politically motivated disappearances and death squads, and has been at the center of the fiercest debates over successor regimes' obligation to investigate and prosecute. It therefore provides an excellent illustration of the legal and pohicy problems at issue. At the same time, this Comment will refer to mternational law and practice more generally, because an mternational obhigation to investigate and prosecute cannot be limited in application to Latin American countries.

Part I of this Comment describes and explains the special characteristics of disappearances and death squads. It then recounts the history of several successor regimes' decisions to cut short prosecution of violators linked with the prior regime. Part I concludes that due to these denials of responsibility, victims gain no redress, and the impression remains that future repressive actions will also be immune. To avoid the continuing cycle of repression, the only remedy must be the recoguition of an affirmative obligation on governments to imvestigate and prosecute gross

2. By "grave human rights violations" I refer to those acts that violate an individual's right to life and/or physical and mental integrity - killings, disappearances, and torture. Other authors have used the phrase "criminal violations of human rights" to describe this limited set of violations. See Rodley, The International Legal Consequences of Torture, Extra-Legal Execution, and Disappearance, in New Directions in Human Rights 167, 167 (E. Lutz, H. Hannum \& K. Burke eds. 1989). The extent to which the obligation discussed here may be applicable to a broader range of rights violations is beyond the scope of this Comment.

By "prosecute" or "take action against," I intend to denote a whole range of state-enforced actions such as loss of military rank or pension rights, dismissal, fines, or imprisonment. 
state-attributed ${ }^{3}$ human rights abuses.

Part II discusses the conventional law bases for such an obligation in numerous international instruments. It explores three types of provisions that recognize the obligation: criminal law treaties, "ensure and respect" provisions, and many instruments guaranteemg the right to a remedy. Finally, it examines whether the obligation is derogable-that is, whether it can be overcome by contrary domestic law. Specifically, Part II analyzes the amnesty statutes passed by several Latin American governments, and concludes tliat tliey are illegal under international law insofar as they excuse nonderogable obligations to the international community.

Part III considers evidence that there exists a customary law basis for an obligation to mvestigate and prosecute. First, it concludes that the prevalence of similar language in numerous treaties, U.N. resolutions and other documents may reflect the emergence of such a customary norm. Second, it examines state practice whicl, while not uniformly indicative of a norm, is not inconsistent with it. Third, Part III explores how the law of state responsibility for mjury to aliens provides support for the customary norm. Finally, this Section asks whether, if such a customary norm exists, it can be overcome by a sliowing of necessity.

Part IV examines the policy implications of enforcing such an international law norm. The implications differ depending on whether the government is an ongoing violator of human rights or a successor government trying to overcome the legacy of a repressive dictatorship. The Comment concludes that, although the policy questions are thorny and the answers not clear-cut, on balance the cause of human rights and democracy is served by international insistence on an affirmative obligation on states to investigate grave human rights violations and to take action against the violators. ${ }^{4}$

I

\section{STATE DENIAL OF RESPONSIBILITY FOR HUMAN RIGHTS VIOLATIONS}

\section{A. The Nature of Disappearances and Death Squads}

While torture, political imprisonment, and killing of pohitical opponents are not new, in recent years governments have developed novel forms of repression. Most important are the related techniques of forced

3. In international law, "state" and "municipal" refer to countries, not to their subdivisions.

4. Although this Comment argues for the existence of an international law norm, its scope does not permit a detailed discussion of how such a norm could be enforced. The most promising enforceinent mechanism in the Americas, however, may be the Inter-American Court of Hunian Rights because of its recent construction of the American Convention on Human Rights. See infra text accompanying notes $95-130$. 
disappearance and use of paramilitary forces to carry out repressive activities. Large-scale forced disappearances began in Guatemala in the late 1960s; to date nearly 40,000 people have been "disappeared" for political reasons in that country. ${ }^{5}$ But world attention focused on the problein only after it came to liglit that thousands of people in Chile and Argentima lad disappeared during the 1970 s. $^{6}$ In addition to its prevalence in Guatemala, Chile and Argentima, the technique has been widely used in Uruguay, El Salvador, Afglianistan, Ethiopia, the Philippines, Equatorial Guinea, Sri Lanka, Deinocratic Kampuchea (Cambodia), and Uganda. ${ }^{7}$ Among the countries notorious for deatlı squad killings by groups directly or indirectly linked to the governments are Guatemala, E1 Salvador, Sri Lanka, Soutli Africa, and tlie Philippimes. ${ }^{8}$

There are two mam elements of a forced disappearance: first, "abduction or detention . . . by an agent of a State or by a person acting witli the consent or acquiescence of a State," and second, official refusal to acknowledge tlie abduction or to disclose or make available information that would reveal the detainee's fate or whereabouts. ${ }^{9}$ Those abducted are detained, tortured, and, typically, killed. ${ }^{10}$ A deatli squad killing similarly imvolves state involvement or complicity and a demial of responsibility, but differs im that the body-almost always slrowimg signs

5. Americas Watch Comm., Closing the Space: Human Rughts in Guatemala May 1987-OCTOBER 1988, at 5 (1988) [hereinafter AW, GUATEMALA]. Reportedly, 100,000 have been killed. Id. Nazi Germany also employed a type of forced disappearance. Under the 1941 Nacht und Nebel (Night and Fog) Decree, 7,000 people arrested on suspicion of endangering German security were secretly transferred to concentration camps in Germany, with their families receiving no information on their whereabouts. AMNESTY INTERnational USA, DISAPpEARANCES: A WORKBOOK 2 (1981) [hereinafter AI, DisAppEARANCES]. Since the German military inade no apparent attempt to disguise state involvement, their practices differ from those at issue in this Comment.

6. AI, Disappearances, supra note 5, at 2.

7. Asia Watch Comm., Cycles of Volence: Human Rights IN SRI LaNka since the INDO-SRI LANKA AGREEMENT 31 (1987) [hereinafter AW, SRI LANKA]; Bennan \& Clark, State Terrorism: Disappearances, 13 RUTGERS L.J. 531, 532-33 (1982); see also Amnesty International annual reports, 1980 through 1988 (specific country sections).

8. See Americas Watch \& ACLU, As Bad As EVER: A Report on Human RightS in El SALVADOR 13 (1984) [hcreinafter AW \& ACLU, EL SALVADOR] (government responsible for or comphicit in disappearances of suspected opponents); AMNESTY INTERNATIONAL, GUATEMALA: A GOVERNMENT-SPONSORED CAMPAIGN OF TERROR (1981) [hereinafter AI, GUATEMALA] (same); AmNesty INTERnational, Report of AN AI Mission to the Philippines $43-49$ (1981) [heteinafter AI, Philfppines] (same); LAwYers COMM. FOR INTERNATtonal Human RIGHTS, Salvaging Democracy: Human Rights in the PhIl PPINES 44-53 (1985) (disappearances continue); AW, SRI LANkA, supra note 7, at 31; Pretoria Rights Abuses-Dramatic Disclosures, S.F. Chron., June 2, 1990, at A15, col. 5.

9. Draft Inter-American Convention on the Forced Disappearance of Persons, INTER-AM. C.H.R. 351-57, OEA/ser. L./V/MI.74, doc. 10 rev. 1 (1988), at 351-57; see also Forti v. SuarezMason, 694 F. Supp. 707, 710 (N.D. Cal. 1988) (finding that "causing disappearance" is a universally proscribed tort in violation of the law of nations).

10. Berman \& Clark, supra note 7, at 533 . 
of torture or mutilation-is deliberately left where it can be found. ${ }^{11}$

The organizational structure of the groups responsible for committing forced disappearances or death squad killing can vary from country to country. In some cases a centralized government agency-typically the military command-coordinates the planning and execution of these operations. ${ }^{12}$ In others, while the military high command makes the decision to engage in disappearances or killings, the planning and execution are left to the intelligence sections of each military regiment or battalion. ${ }^{13}$ Soine Central American countries augment the decentralized approach by using irregular forces, which include off-duty military and police personnel as well as civilians, in a system with overall military command. $^{14}$

The use of disappearances and death squads, rather than outright official execution, serves several internal purposes for the repressive regimes. It allows thein to get rid of actual, potential, and perceived opponents without the publicity of a public trial or the risk of creating martyrs through the imposition of death sentences. It also terrorizes broad sections of the population, who live with the uncertainty of not knowing whether their relatives, neighbors, or co-workers are dead or alive. Thus one government action serves to punish family and friends as well as the victin herself. In death squad killing cases, while there is no uncertainty about the victim's fate, there is the generalized horror of hiving in a soeiety where mutilated corpses turn up daily with no explanation. Where there is no obvious link to pohtical or social activism, those who knew the person may not understand why she has disappeared or been killed and fear that they themselves might be next. The terror and uncertainty create a chilling effect on pohtical activity in general. Perhaps most significantly, the use of the mechanisuns of disappearance and death squad killings allows the governinent to avoid aceountability for its actions by making it difficult for citizens to find effective ways to press for either the release or the formal trial of a detainee.

$[W]$ hen governments claim that disappearances [and paramilitary kidnappings and killings] are outside of their realm of responsibility, they render meaningless the major legal recourses available to families and

11. See sources cited supra note 7.

12. The Directorate of Intelligence (DINA) in Chile after the 1973 coup is a typical example. See AI, Disappearances, supra note 5, at 92-95.

13. This was the inodel used in Argentina. Id. at 95-98.

14. Id. at 100-05. These irregular forces are responsible for both disappearances and death squad killings. See AW, GuATEMALA, supra note 5. In addition, private armies paid by landowners may sometimes be responsible for similar killings; however, in Latin America at least, the vast majority of death squad-type killings have been government-sponsored or condoned. See id. State responsibility for the actions of private parties where the government is not complicit and does not condone the actions raises a host of difficult and interesting problems, but is beyond the scope of this Comment. 
other concerned persons .... . Since there is no body or no corpse one cannot estabhish that a crime has been committed. There is no way to be sure of the range of [sic] extent of the rights which are actually being violated. The word of governments denying responsibility . . . inust be judged against that of unprotected civilian witnesses to the arrest. ${ }^{15}$

These activities are clearly illegal under international law, as well as under the doinestic law of every country prohibiting inurder and kidnapping. State-sponsored death squad killings violate the international prohibitions in major human rights treaties against summary execution. ${ }^{16}$ The treaty provisions do not deal specifically with disappearances, but both disappearances and state-initiated or condoned killings violate rights defined in the Universal Declaration of Human Rights, ${ }^{17}$ the International Covenant on Civil and Political Riglits, ${ }^{18}$ the American Declaration on the Rights and Duties of Man, ${ }^{19}$ and the American Convention on Human Rights. ${ }^{20}$ Both practices also violate custornary international law. ${ }^{21}$

Death squad killings and disappearances have been recognized as a serious problein by the U.N. General Assembly ${ }^{22}$ and condemned by the Organization of American States. ${ }^{23}$ Disappearance has also been characterized as a crime against humanity, and as a crime of state. ${ }^{24}$ The United Nations estabhished both a Special Rapporteur on Suınınary or Arbitrary Executions ${ }^{25}$ and a Working Group on Enforced or Involuntary Disappearances, to enhance U.N. capacity to deal with disappear-

15. Human Rights and the Phenomenon of Disappearances: Hearings Before the Subcomm. on International Organizations of the House Comm. on Foreign Affairs, 96th Cong., 1st Sess. 79 (1979) [hereinafter Human Rights Hearings] (statement of Patricia Fagen, Executive Director, Amnesty International).

16. See e.g., Restatement (THIRD) OF Foreign RELATIONS LAW OF THE UN1TED STATES $\S 702$ (c) reporter's note 2 (1987) [hereinafter RESTATEMENT].

17. See Universal Declaration of Human Rights, G.A. Res. 217 (III), arts. 3, 5, 9, 10, U.N. Doc. A/810, at 71 (1948) [hereinafter Universal Declaration].

18. International Covenant on Civil and Pohtical Rights, Dec. 19, 1966, 999 U.N.T.S. 171, arts. 6, 7, 9 [hereinafter International Covenant].

19. American Declaration of the Rights and Duties of Man, May 2, 1948, OEA/ser. L. $N /$ 11.23, doc. 21 rev. 6, arts. I, XXV (1979), reprinted in Basic Documents Pertaining to Human Rights in the Inter-American System, OEA/ser. L. N/II.71, doc. 6 rev. 1 at 27 (1988) [hereinafter Basic Documents].

20. American Convention on Human Rights, Nov. 22, 1969, 36 O.A.S.T.S. 1, arts. 4, 5, 7, OEA/ser. L./V/II.23, doc. 21 rev. 6 (1979) (entered into force July 18, 1978) [hereinafter American Convention], reprinted in Basic Documents, supra note 19, at 25.

21. Forti v. Suarez-Mason, 694 F. Supp. 707, 710 (N.D. Cal. 1988); RestatEment, supra note $16, \S 702$ (c).

22. G.A. Res. 33/173, 33 U.N. GAOR Supp. (No. 45) at 158, U.N. Doc. A/33/45 (1979).

23. O.A.S.G.A. Res. 666 (XIII-0/83), 1 OEA/ser. P./XIII.0.2 (1983).

24. Berman \& Clark, supra note 7, at 547-50; see also supra notes 16-23.

25. E.S.C. Res. $1982 / 35,1982$ U.N. ESCOR Supp. (No. 1) at 27 , U.N. Doc. E/1982/82 (1982). 
ances and paramilitary killings. ${ }^{26}$

Prohibitions against torture, summary execution, and prolonged arbitrary detention found their way into customary international $l a w^{27}$ at the same time that the international human rights commumity became more effective at publicizing and arousing worldwide condemnation of the worst governmental abuses. In response, governments tried to disguise official involvement by developing and using the techniques of disappearances and death squad killings as ways to silence their opponents. One human rights activist noted:

I feel what is important is that torture is becoming abhorrent to most of the civilized world and that at least there is reaction against torture. It is becoming a hability as an imstrument of repression ... . If world indignation begins to deny [repressive regimes] the use of torture or arbitrary and prolonged detention or horrendous inhuman prison conditions as a means of intimidation and control then some other imstrument must and will be developed. The phenomenon of disappearances . . . is one of the newest manifestations of the fulfillment of this requirement of repression .... [O]ffending goveruments feel no obligation to account for disappeared persons or to acknowledge their responsibility for such violations. They are left without victims who walk around and embarrass them. Disappearance is tidier than torture. ${ }^{28}$

Resort to disappearances and use of death squads allows governments to avoid responsibility to the international commumity. Governments deny all knowledge of repressive actions and cloak the repression in extreine secrecy. For example, although the impact of the Argentime "anti-subversive" campaign was well known in the world community, there was little solid evidence of sufficient credibility and specificity to satisfy a court of law.

26. The Working Group was created in 1980. Question of Human Rights of All Persons Subjected to Any Form of Detention or Imprisonment, In Particular: Question of Missing and Disappeared Persons: Report of the Working Group on Enforced or Involuntary Disappearances, 37 U.N. Comm'n on Hum. Rts. (Provisional Agenda Itein 10(b)) at 6, U.N. Doc. E/CN.4/1435 (1981). In its first report, the Working Group noted that the vast inajority of its cases dealt with persons who had been "arrested, detained or abducted by personnel belonging to a body which was either established as or beheved to be, an organ of the Government; or controlled by Government; or operating with the overt or latent coinplicity of Government; and the Government concerned in these cases neither accepted responsibility for the arrest, detention or abduction, nor accounted for these actions." Id. By late 1986, the Workiug Group had asked governments for information concerning 14,000 alleged disappearances, and the number of reported cases was still risiug. 43 U.N. Comm'n ou Hum. Rts. (Provisional Agenda Itein 10(c)) at 45, U.N. Doc. E/CN.4/1987/15 (1986).

27. The RESTATEMENT, supra note 16, lists "inurder or causing the disappearance of individuals," "torture or other cruel, inhuman or degrading treatınent or punishment," and "prolonged arbitrary detention" as violating generally accepted custoinary law. Id. § 702(c)-(e). Indeed, the prohibitions on summary execution and torture, at least, may uow have the status of $j u s$ cogens, that is, rights that a state cannot derogate. Id. comment n. For a discussion, see Lillich, Civil Rights, in HuMAN Rights IN INTERNATIONAL LAw 115, 115-18 (T. Meron ed. 1984).

28. Human Rights Hearings, supra note 15, at 140-41 (statement of William Wipfler, National Council of Churches). 
Orders were given orally in inost cases, requiring the cooperative testiinony of junior officers who are constitutionally entitled to the right against self-incrimination. Written orders were either unsigned or couched so vagnely as to communicate their true intent only by "subliminal intimation" ... . Official statements during military rule denied any illegality . . . . Kidnappers drove unmarked cars; torturers wore no uniforms and einployed pseudonyms; victims were kept blindfolded; detention centers were often established on private rather than public property. ${ }^{29}$

Thus, even if the pohtical will existed to bring the perpetrators to justice, government secrecy and denials make it hard to find sufficient evidence. Unfortunately, that political will has often proved lacking.

\section{B. The Problem of Successor Governments}

The question whether states have an affirmative obhigation to investigate and take action against those who have engaged in state-directed or condoned disappearances or killings has been posed most starkly in those countries where notoriously repressive regimes have been replaced by elected civilian governments. During the last seven years, the countries of the southern cone of South America have attempted to come to grips with past human rights abuses. The tensions have by no means been resolved and, in the case of Chile, are just beginning. The experiences of Argentina, Uruguay and Chile illustrate the pressures on successor governments to refrain from prosecuting prior violators, and denionstrate the need to clarify their international obligations.

Argentina was the first country in the southern cone to replace its repressive regime. It was discovered that during military rule from 1976 to 1983 , some 9,000 people disappeared-kidnapped by special military squads, tortured, imprisoned, and in most cases killed. ${ }^{30}$ The military demed knowledge of their whereabouts, and the victims' families obtained little redress through the courts. ${ }^{31}$

After President Raul Alfonsin took office im 1983, the governinent announced that it would try military officers for human rights violations, beginning with the nine individuals who had headed the three successive military juntas from 1976 to $1983 .^{32}$ Special legislation granted a mili-

29. Osiel, The Making of Human Rights Policy in Argentina: The Impact of Ideas and Interests on a Legal Conflict, 18 J. LAT. AM. STUD. 135, 145 (1986). Then-President Alfonsín appointed a blue-ribbon commission to take testimony and investigate the extent of the violations, since, among other reasons, the amount of necessary investigatory work surpassed the capacities of any prosecutor. Id.

30. Americas Watch COMm., Truth and Partial Justice in ARgentina 21-24 (1987) [hereinafter AW, ARgentina] (citing National CoMm'N ON Disappeared Persons, Nunca Mas (1984) (English 1986)); see also Osiel, supra note 29, at 139.

31. See sources cited supra note 30.

32. AW, ARGENTINA, supra note 30, at 14-16. 
tary tribunal-the Supreme Council of the Armed Forces-jurisdiction over the prosecutions, with appeal to civilian courts if no decision was rendered within 180 days after a case was opened. Moreover, the law mcluded a clause exculpating those officers who had believed their orders legitimate, unless the officers exceeded tlie orders or committed "atrocious and aberrant acts."33 After 180 days passed with no action from the Supreme Council on the nine junta members' cases, the civilian Federal Court of Appeals for Buenos Aires assumed jurisdiction ${ }^{34}$ and found, after a dramatic trial, that a systematic plan of covert repression had existed. ${ }^{35}$ The court sentenced five of the nine junta members to prison. ${ }^{36}$ By 1985 over 2,000 criminal complaints imitiated by victims and their families were pending against some 650 officers. ${ }^{37}$ The government, worried about coup attempts by a restless military imterested in protecting accused active-duty officers, issued instructions to military prosecutors to drop cases where due obedience was a factor. ${ }^{38}$ In late 1986, Alfonsin pushed through the legislature a "full stop" law, which provided that all new criminal complamts against the military for human rights abuses during the so-called "war agamst subversion" had to be brought within sixty days, and that most pending complamts would be considered moot unless the courts undertook a certain procedural step within the saine sixty days. ${ }^{39}$ Because human rights organizations raced against the deadline, filing complamts and submitting further evidence in support of complamts already filed, hundreds of officers still faced charges after sixty days had passed..$^{40}$ Shortly thereafter, army officers temporarily took over a military compound and demanded an aninesty law. ${ }^{41}$

On June 5, 1987, the military received a partial amnesty im the form of a "due obedience" law, under which all but the most semor officers were granted an irrebuttable presumption that they erred in believing the orders legitimate, and so were not criminally liable. Fewer than fifty

33. Id. at 18-19. Although "atrocious and aberrant" acts were never defined, they apparently refer to crimes against humanity. Id. For definitions of "crimes against humanity," see infra note 58.

34. Id. at 29 .

35. Id. at 34-37.

36. Id.

37. Id. at 61. The Argentine criminal justice system permits a criminal proceeding to begin with a denuncia brought by a civilian victim. The "planitiff-prosecutor" then works closely with the state throughout the trial. Victims or their families file criminal charges and remain in the case as a party to the prosecution, and may ask for damages as well as imcarceration or other criminal penalties. Mignone, Estlund \& Issacharoff, Dictatorship on Trial: Prosecution of Human Rights Violations in Argentina, 10 YALE J. INT'L L. 118, 123 (1984).

38. AW, ARGENTINA, supra note 30, at 62-63.

39. Id.

40. Id.

41. Id. at $64-68$. 
senior officers, in addition to individuals accused of rape, abduction of children, or falsification of children's identity papers were still subject to prosecution. $^{42}$ Alfonsín's successor, President Saul Menen1, has now reversed course entirely, pardoning almost all remaining officers despite large-scale popular protests agamst the measure. ${ }^{43}$

Uruguay has also grappled with how to address past human rights violations. The military that ruled Uruguay from 1973 to 1985 was responsible for disappearances and the widespread use of torture and prolonged arbitrary imprisonnient. ${ }^{44}$ Soon after Julio Sanguinetti was elected president on a platform that included brimging the military to justice, the courts received nunierous criminal complaints fron1 victims and their fainilies. ${ }^{45}$ However, before the opening of hearings in several of sone forty cases pending against 180 military officers, Sanguinetti proposed an amnesty law. The ruling party pushed a bill through the legislature precluding the state's ability to seek punishment for most of the military's hunian rights violations before $1985 .{ }^{46}$

Uruguayan citizens challenged the amnesty law under a constitutional provision allowing a referendum on any law if $25 \%$ of registered voters so request. ${ }^{47}$ After a heated petition drive, marked by repeated government attenipts to disqualify voters' signatures, over 600,000 signatures were filed-more than enough to force the referendum. ${ }^{48}$ In April 1989 , after a government-backed scare campaign, ${ }^{49}$ the referendum was defeated. ${ }^{50}$

Chile, where a civilian president began his term in March 1990, faces similar dilemmas. Thousands of people were killed by the military in the years immediately following a 1973 coup, and hundreds remain

42. Id. at 68-72.

43. Argentina to Pardon Ex-Officers, N.Y. Times, Sept. 19, 1989, at 10, col. 1.

44. Americas Watch Comm., Challenging Impunity: The Ley de Caducidad and the Referendum Campaign IN URuguay 5-9 (1989) [heremafter AW, Challenging IMpunity]. For an essay on Uruguay's recent history, see Weschler, $A$ Reporter at Large: The Great Exception (pts. 1 \& 2), THE New YoRKeR, Apr. 3 \& 10, 1989.

45. AW, Challenging IMPUnITY, supra note 44, at 11-13.

46. Id. at 13-17. The law, called the Law Nullifying the State's Claim to Punish (Ley de Caducidad de la Pretension Punitiva del Estado) was not the amnesty requested by Sanguinetti, but it had the same effect because the government could not prosecute in those cases where due obedience was a factor or where political motives existed. The law exempted crimes committed by the military high command and required that the executive branch investigate reports of disappearances and take administrative measures to inform the victims' families. Id. The military prosecutor investigating disappearance cases found "insufficient evidence" to loold anyone responsible. Id. at 21.

47. Id. at 26.

48. Id. at 26-27, 28-40.

49. For example, the Defense Ministry allowed unprecedented and highly publicized military war games to begin shortly before the referendum. Weschler (pt. 2), supra note 44, April 10, 1989, at 108.

50. L.A. Times, Apr. 17, 1989, at 6, col. 1 . 
unaccounted for. ${ }^{51}$ Before taking office, spokespersons for the winning coalition declared that it would ask the incoming congress to overturn a 1978 amnesty statute ${ }^{52}$ and to suspend the statute of limitations on murder. ${ }^{53}$ In April 1990, President Aylwin created a National Commission of Truth and Reconciliation to investigate alleged human rights violations under the prior regime and to recommend coinpensation for victims or their families. ${ }^{54}$ The military has already warned that it will not accept any prosecutions for human rights abuses. ${ }^{55}$

In all these cases, the successor regime is not responsible for the grave human rights violations of its predecessors. Yet letting the new government preclude all possibility of civil suit or criminal prosecution leaves the victims with no redress and encourages a behef that future repressive tactics will be granted immumity. With no fear of retribution, each new regime can again succumb to the same repressive behavior. These problems can only be remedied by placing an affirmative obhigation on the state to investigate and prosecute past rights violators.

The obhigation should apply whether the past gross violations are open or concealed. It becoines crucial when the past violations were designed precisely to create enormous probleins of proof for subsequent investigators and to avoid increased international scrutiny of government human rights practices. In inost of Latin America, disappearances and death squad killings served (and still serve) exactly these purposes. Therefore, the international cominunity must respond by developing new methods to hold governments accountable for these actions. The burden of proof under international law must shift to the government to show that it is not responsible for such practices. In addition, the law must inipose a nonderogable, affirmative obligation on all governments, including successor governments, to investigate and take action against the perpetrators. This Comment argues that international law, in both treaties and custoin, ${ }^{56}$ is beginning to reflect such a shift.

Part II of this Comnient explores the conventional (treaty) law bases

51. Americas Watch Comm., Chile Since the Coup: Ten Years of Repression 47 (1983).

52. Decrec-Law No. 2191 of April 18, 1978.

53. Chilean General Warns Opposition on Amnesty, N.Y. Times, Aug. 1, 1989 at A4, col. 4 [hereinafter Chilean General].

54. Chile Sets up Limited Human Rights Probe, Fin. Times, Apr. 26, 1990, at 4.

55. Chilean General, supra note 53.

56. International law can be found in two main sources: treaties between or among states, and custom, including general principles of law. Statute of the International Court of Justice, art. 38, 59 Stat. 1055, T.S. No. 993 (1945), reprinted in 1976 U.N.Y.B. 1052. There is also growing agreement that certain basic rights are jus cogens, that is, peremptory norms that all states are bound to respect, whether or not they have explicitly consented to do so. A treaty whose provisions conflict with a peremptory norm of international law is void. Vienna Convention on the Law of Treaties, adopted May 23, 1969, art. 53, 1155 U.N.T.S. 331 [hereinafter Vienna Convention]. 
for the obligation to investigate and prosecute grave human rights violations, while Part III will discuss the customary law evidence for the existence of such an obligation.

\section{II}

\section{Treaty-Based Sources of an Obligation to INVESTIGATE AND PROSECUTE}

Human rights law has only recently provided rights to individuals vis-à-vis their own states. Due to widespread revulsion for the crimes committed immediately before and during the Second World War, nations finally began to accept limits on their absolute sovereignty regarding the human rights of those residing within their jurisdictions. A series of widely subscribed multilateral instruments now define many of these rights. ${ }^{57}$

Three different types of clauses in inodern inultilateral human rights treaties provide support for a state's obligation to investigate grave human rights violations and take action against the responsible parties. First, criminal law treaties specify the obligation of states to prosecute and pumish perpetrators of acts defined as crimes under international law. Second, the "ensure and respect" provision common to many treaties has been interpreted, by at least one court, to impose affirmative obhgations on states to investigate and prosecute. Finally, the right to a remedy included in many human rights instruments provides a strong basis for inferring an obligation to investigate and prosecute.

\section{A. Criminal Law Provisions}

The Nureinberg prosecutions of Nazi war criminals and the prosecutions of high-ranking Japanese officers after World War II confirmed that war crimes and crimes against humanity are offenses punishable under international law. ${ }^{58}$ The Nureinberg Tribunal was unusual in that

57. These instruments include the U.N. Charter, the Universal Declaration of Human Rights, the International Covenant on Civil and Pohtical Rights, the International Covenant on Economic, Social and Cultural Rights, see supra text accompanying notes 17-20, and somc fifty additional declarations and conventions on specific human rights and humanitarian law issues. Sohn, The New International Law: Protection of the Rights of Individuals Rather than States, 32 AM. U.L. REV. 1, 912 (1982).

58. Affirmation of the Principles of International Law recognized by the Charter of the Nuremberg Tribunal, G.A. Res. 95, U.N. Doc. A/64/Add.1, at 188 (1946) [hereinafter Nuremberg Principles]. The Charter of the International Military Tribunal, annexed to the London Agreement for the Prosecution and Punishment of Major War Criminals of the European Axis, Aug. 8, 1945, art. 6 (c), 59 Stat. 1544,1547 , E.A.S. No. 472,82 U.N.T.S. 279,288 , defines crimes against humanity as follows:

murder, extermination, enslavement, deportation, and other inhumane acts committed against any civilian population, before or during the war; or persecutions on political, racial or religious grounds in execution of or in connection with any crime within the jurisdiction of the Tribunal. . . . 
it was an international court applying its own law; most criminal law treaties commit the parties to use national laws and tribunals to define the offenses to be prosecuted.

The principle aut dedere aut judicare-extradite or prosecutedates back to Grotius, ${ }^{59}$ one of the earhest international legal scholars, and has been included in the Convention on the Prevention and Punishment of the Crime of Genocide, ${ }^{60}$ the 1949 Geneva Conventions, ${ }^{61}$ the Convention Against Torture and Other Cruel, Inhunian or Degrading Treatinent or Punishment, ${ }^{62}$ and several conventions relating to terror-

In its Judgment, the Nuremberg Tribunal found that repressive acts carried out before the onset of war could not be called crimes against humanity, becanse they were not committed im execution of or in connection with war or with crimes against peace. Trial of the Major War Criminals, (Nuremberg) 1948 Int'l Military Tribunal 22, at 497-98 (1946. Thus, politically motivated killings or disappearances in Latin America would not be covered by this narrow definition. The Judgment's language inay derive from the unprecedented international nature of the Nuremberg Tribunal.

In contrast, the definition of "crimes against humanity" given in Allied Control Council Law No. 10 of Dec. 20, 1945 is similar but does not require a counection to the war. Trial of War Criminals Before the Nuremberg Military Tribunals under Control Council Law No. 10, 1946, Nuremberg Military Tribunals 1, at XVI. Control Council Law No. 10 was promulgated to provide a legal basis for prosecution by German courts of suspected war criminals and other offenders. 3 INTERNATIONAL CRIMINAL LAW 108 app. at 129 (M. Bassioumi ed. 1987) [hereinafter INT'L CRIM. LAw]. Like the obligation to prosecute at issue in this Comment, the Council law applied to prosecution in the domestic courts of the offender; it is therefore a inore appropriate definition of "crimes against humarity," and would cover the grave violations at issue in Latin America.

Many jurists have since expanded the concept of crimes against humanity to include egregious violations of human rights, like torture, summary execution, and disappearance. See, e.g., Velasquez Rodriguez Case, Inter-Am. Ct. H.R. 35, OAS/ser.L./V/III.19, doc. 13, app. VI II 149-158 (1988) (noting that international practice and doctrine often characterize disappearances as crimes against humanity). The International Law Commission's Draft Code of Offenses Against the Peace and Security of Mankind defines crimes against humarity independently of their relation to war, to include any of the above-cited offenses committed against elements of a population on social, political, racial, religious, or cultural grounds. Summary Records of the 1957th Meeting, [1986] 1 Y.B. INT'L LAW COMM'N 85, 87, U.N. Doc. A/CN.4/SER.A/1986. The same draft code defines war crimes as "[a]ny serious violation of the laws or customs of war." Id. at 88.

59. 2 H. Grotius, De JuRE Belli et PaCis (The Rights of WAR AND PEACE), ch. XXI, $\S$ IV (1), at 347 (W. Whewell trans. \& ed. 1853).

60. Dec. 9, 1948, T.I.A.S. No. - , 78 U.N.T.S. 277, 280 [hereinafter Genocide Convention]. The United States Senate gave its consent to the Convention in 1986, see S. 2803, 99th Cong., $2 d$ Sess., 132 CONG. REC. DO0000-01 (1986), but inplementing legislation was not adopted until 1988. See S. 1851, 100th Cong., 2d Sess., 134 CoNG. REC. H10441-02 (1988).

61. Geneva Convention for the Amelioration of the Condition of the Wounded and Sick in Armed Forces in the Field, Aug. 12, 1949, art. 49, 6 U.S.T. 3114, 3146, T.I.A.S. No. 3362, 75 U.N.T.S. 3162 [hereinafter Geneva Convention I]; Geneva Convention for the Amelioration of the Condition of Wounded, Sick and Shipwrecked Members of Armed Forces at Sea, Aug. 12, 1949, art. 50, 6 U.S.T. 3217, 3250, T.I.A.S. No. 3363, 75 U.N.T.S. 85, 116 [hereinafter Geneva Convention II]; Geneva Convention Relative to the Treatment of Prisoners of War, Aug. 12, 1949, art. 129, 6 U.S.T. 3316, 3418, T.I.A.S. No. 3364, 75 U.N.T.S. 135, 236 [hereinafter Geneva Convention III]; Geneva Convention Relative to the Protection of Civilian Persons in Time of War, Aug. 12, 1949, art. 146, 6 U.S.T. 3516, 3616, T.I.A.S. No. 3365, 75 U.N.T.S. 287, 386 [hereinafter Geneva Convention IV].

62. GA Res. 39/46, 39 U.N. GAOR Supp. (No. 51) at 197, U.N. Doc. A/39/51 (1984)

[hereinafter Torture Convention]. 
ism. ${ }^{63}$ The purpose of the principle is to ensure that those who commit crimes under international law are not granted safe haven anywhere in the world.

The Genocide Convention, one of the earliest human rights treaties, ${ }^{64}$ specifically requires punishment of offenders. ${ }^{65}$ Article 4 states: "Persons committing genocide or any of the acts enumerated in article 3 sliall be punished, whether they are constitutionally responsible rulers, pubhic officials or private imdividuals." vide effective penalties" for persons guilty of genocide or related offenses. ${ }^{67}$ Article 6 provides for trial by "a competent tribunal" of the state where the act occurred or by an international penal tribunal. ${ }^{68}$

The 1949 Geneva Conventions ${ }^{69}$ provide that the High Contracting Parties

shall be under the obligation to searcli for persons alleged to have committed, or to have ordered to be committed, such grave breaches [war crimes], and shall bring sucl persons, regardless of their nationality, before its own courts ... [or] hand such persons over for trial to another High Contracting Party .... ${ }^{70}$

In addition, international agreements to outlaw and punish hijacking, ${ }^{71}$

63. See infra notes 71-74.

64. Genocide is defined in article 2 of the Convention as "any of the following acts committed with intent to destroy, in whole or in part, a national, ethnical, racial or religious group as such:

a) Killing inembers of the group;

b) Causing serious bodily or inental harm to ineinbers of the group;

c) Deliberately inflicting on the group conditions of life calculated to bring about its physical destruction in wliole or in part;

d) Inposing ineasures intended to prevent birtls within the group;

e) Forcibly transferring children of the group to another group.

Genocide Convention, supra note 60 , art. 2.

65. Id. art. 4.

66. Id.

67. Id. art. 5 .

68. Id. art. 6. Article 4 of the United Nations Convention on the Non-Applicability of Statutory Limitations to War Crimes and Crimes Against Hunanity, Nov. 26, 1968, 754 U.N.T.S. 73 [hereinafter Statutory Limitations Convention] also contains language suggesting a statc's responsibility to prosecute. It commits state parties to adopt legislative or other ineasures necessary to ensure that "statutory or other limitations shall not apply to the prosecuticn and punishment of the crimes [war crimes, genocide, inhuman acts resulting froin apartheid and crimes against humanity] referred to in articles I and II . . . and that, where they exist, such limitations shall be abolished." 754 U.N.T.S. at 76. Crimes against humanity are covered wlether committed in time of war or in time of peace. Id. at 75. The purpose of a prohibition on statutes of limitations is obviously to facilitate prosecution by states under their own domestic law. However, the Convention's usefulness may be limited because only 28 states have signed it.

69. See supra note 61 .

70. Geneva Convention IV, supra note 61, art. 146.

71. Convention for the Suppression of Unlawful Seizure of Aircraft, Dec. 16, 1970, art. 7, 22 U.S.T. 1641, 1646, T.I.A.S. No. 7192, 860 U.N.T.S. $105,109$. 
aircraft sabotage, ${ }^{72}$ the taking of hostages, ${ }^{73}$ and terrorisin ${ }^{74}$ all include provisions calling for state parties either to submit the case of an alleged offender for prosecution under the state's own laws or to extradite him to a country that will prosecute him.

It might be argued that these provisions apply only to crimes of an international character, and thus the growing use of such provisions does not reflect a broad obligation to extradite or prosecute. The Geneva Conventions language cited above, for example, technically applies only to war crimes committed withni the context of an international conflict. ${ }^{75}$ Article 3 of those Conventions, dealing with armed conflicts within a single country, does not contain explicit language regarding extradition or prosecution. ${ }^{76}$ Hijacking and aircraft sabotage almost always involve more than one country. But extradite or prosecute provisions have been used in specifically national contexts as well. The Torture Convention, which does primarily apply to a state's treatment of its own nationals, ${ }^{77}$ also contains very clear "extradite or prosecute" provisions. ${ }^{78}$ It also contains, in articles 12 and 13, the clearest language to date requiring national authorities to receive and investigate complaints from alleged victims. ${ }^{79}$ Finally, article 14 requires states to provide redress as well as

72. Convention for the Suppression of Unlawful Acts Against the Safety of Civil Aviation, Sept. 23, 1971, art. 7, 24 U.S.T. 565, 571, T.I.A.S. No. 7570, 1971 U.N. JURID. Y.B. 143, 145, U.N. Doc. ST/LEG/SER.C/9.

73. International Convention Against the Taking of Hostages, Dec. 17, 1979, art. 8, U.N.G.A. Res. 34/146, 34 U.N. GAOR Supp. (No. 46) at 245, 246, U.N. Doc. A/C6/34/46 (1979).

74. European Convention on the Suppression of Terrorism, Jan. 27, 1977, art. 7, Europ. T.S. No. 90 , at 3 .

75. Van Den Wijngaert, War Crimes, Crimes Against Humanity, and Statutory Limitations, in INT'L CRIM. LAw, supra note 58, at 90.

76. Nonetheless, the International Court of Justice, Military and Paramilitary Activities in and Against Nicaragua (Nicar. v. U.S.), 1986 I.C.J. 14, 114 [hereinafter Nicaragua case], found that provisions of the Geneva Conventions included in the sections on international conflicts applied to domestic conflicts as well.

77. Article 2 of the Torture Convention requires each state party to take effective ineasures to prevent acts of torture in territory under its jurisdiction. Torture Convention, supra note 62, at 197. The definition of torture in article 1 of the Convention is limited to acts inflicted by or at the instigation of (or with the consent or acquiescence of) a public official or other person acting in official capacity. Id. Thus, the Convention clearly applies to torture committed by and against nationals of the same state.

78. Id. at 198. Article 7 of the Convention reads:

1. The State Party in the territory under whose jurisdiction a person alleged to have committed any offense referred to $\mathrm{m}$ article 4 is found shall ..., if it does not extradite hin, subinit the case to its competent authorities for the purpose of prosecution.

2. These authorities shall take their decision in the same manner as in tlie case of any ordinary offense of a serious nature under the law of that state.

Id. Article 4 obligates states parties to ensure that torture, attempts to commit torture, and comphicity or participation in torture are treated as criminal offenses, subject to penalties which "take into account their grave nature." Id.

79. Article 12 commits state parties to "ensure that its competent authorities proceed to a proinpt and impartial investigation, wherever there is reasonable ground to believe that an act of torture has been committed in any territory under its jurisdiction." Id. Article 13 gives alleged 
compensation to those subjected to torture, implying that redress consists of something other than simple compensation. ${ }^{80}$

The provisions of the Torture Convention are easily applicable in cases of disappearance or death squad killing. Almost invariably, the victim of a disappearance or death squad murder is tortured, ${ }^{81}$ although of course in disappearance eases the torture cannot be proved. Disappearances and death squad murders, if characterized as crimes against humanity, are crimes under the Nuremberg Principles, ${ }^{82}$ the Draft Code of Offenses Aganist the Peace and Security of Mankind, ${ }^{83}$ and the Statutory Limitations Convention. ${ }^{84}$ In addition, the Genocide Convention ${ }^{85}$ applies if the killings target specific ethinc or religious groups, and the Geneva Conventions' "grave breaches" provisions apply if the disappearance or death squad murder takes place during armed conflict, ${ }^{86}$ arguably including civil war.

These conventions, whether addressing international or national crimes, show an increasing tendency in imternational law to require states to investigate and prosecute serious offenses. Interest in the international commurity has progressed from acts directly affecting more than one state (war crimes, hijacking) to more indirect concerns based on the enforcement of human rights norms even when the acts themselves affect only nationals of the offending state. ${ }^{87}$ These trends taken together inay

victims of torture the right to complain to, and have their cases examined by, competent authorities. Id. Fimally, article 16 makes the provisions of articles 12 and 13 applicable to other acts of cruel, inhuman, or degrading treatment. Id.

Similarly, the Inter-American Convention to Prevent and Punish Torture, Dec. 9, 1985, 67

O.A.S.T.S., art. 8, reprinted in 25 I.L.M. 519 (1986) (entered into force 1987), provides that

[i]f there is an aceusation or well-grounded rcason to beheve that an act of torture has been committed within their jurisdiction, the States Parties shall guarantee that their respective authorities will proceed ex officio and immediately to conduct an investigation into the case and to initiate, whenever appropriate, the corresponding criminal process.

80. Article 14(1) reads:

Each State Party shall ensure in its legal system that the victim of an act of torture obtains redress and has an enforceable right to fair and adequatc compensation, including the means for as full rehabilitation as possible. In the event of the death of the victim as a result of an act of torture, his dependents shall be entitled to compensation.

Torture Convention, supra note 62, at 198 (emphasis added).

81. See Berman \& Clark, supra note 7, at 532 (disappearance victinis subjected to torture); AI, Guatemala, supra note 8 (death squad victims tortured before being killed); AI, PHILIPPINes, supra note 8 (same); AW \& ACLU, EL SALVADOR, supra note 8 (same).

82. See supra note 58.

83. Id.

84. See supra note 68.

85. See supra note 60 .

86. See supra note 61 ; supra text accompanying notes $75-76$.

87. The Genocide Convention is an exception: it was one of the earliest international conventions, yet it is concerned with states' treatment of their own citizens. Genocide Convention, supra note 60 . However, the international context inmediately following World War II and the transnational nature of Nazi genocide probably explain the early passage of the Convention. 
provide a basis for an emerging consensus that human rights violations must be investigated and prosecuted.

Nonetheless, the applicability of specific penal law treaty provisions is limited both because not all states have signed the treaties and because they do not specifically address the grave human rights violations at issue in this Comment. ${ }^{88}$ But even if specific criminal treaty provisions have limited applicability, there are broader-based human rights treaties that provide additional treaty-based sources of an international obligation to investigate and prosecute.

\section{B. "Ensure and Respect" and the Velasquez Case}

Some early human rights theorists distinguished between "negative" civil and political rights, $m$ which the organs of the state inerely refrained from interfering with individual frecdoms, and "affirmative" social and economic rights. ${ }^{89}$ It is now widely accepted that states have affirmative duties to "ensure" civil and political rights. ${ }^{90}$ Courts and commentators have interpreted treaty provisions obligatimg states to "ensure" pohitical and civil rights as imposing an affirmative obligation to control persons and authorities acting under official auspices.

Professor Buergenthal, now a judge on the Inter-American Court of Human Rights, wrote in 1981: “The obligation 'to ensure' these rights encompasses the duty 'to respect' them, but it is substantially broader. ... The obligation to 'ensure' rights creates affirmative obhigations on the state-for exainple, to discipline its officials . . ."91 Similarly, the European Court of Human Rights has held that the European Convention for the Protection of Human Rights and Fundainental Freedoms "does not merely oblige the higher authorities of the Contractimg

88. The Inter-American Commission on Human Rights has prepared a draft Convention on the Forced Disappearance of Persons, but it has not yet been ratified by any country. See supra note 9.

89. See, e.g., 2 P. Drost, The CRIME of STATE 192 (1959) for an example of the commou distinction drawn betweeu economic, social and cultural rights on the oue hand, and civil and pohtical rights ou the other. Part of the difference stemmed from provisions in the U.N. Iuternational Human Rights Covenants calling for progressive implementation of the former set of rights but not the latter. Compare Internatioual Covenant, supra note 18, art. 2(2), with International Covenant on Economic, Social and Cultural Rights, Dec. 16, 1966, 993 U.N.T.S. 3, art. 2(1).

A good example of a "negative obligation" is the prohibition in the United States Bill of Rights that "Congress shall inake no law . .. " U.S. CoNST. amend. I, which implies that the federal government has no obligation to nurture freedoin of speech, merely an obligation not to inhibit it. For a comparisou of U.S. constitutional and international conceptions of rights, see Henkin, International Human Rights and Rights in the United States, in 1 HumaN RIGHTS IN INTERNATIONAL LAW 25, 34-36 (T. Meron ed. 1984).

90. See, e.g., Buergeutlial, State Obligations and Permissible Derogations, in ThE InTERNATIONAL BILL OF Rights 72 (L. Henkin ed. 1981).

91. Id. at 77. 
States to respect for their own part the rights and freedoms it embodies ... in order to secure the enjoyment of those rights and freedoms, those authorities must prevent or remedy any breach at subordinate levels." ${ }^{92}$ The Geneva Conventions of 1949 also contain an "ensure and respect" provision. Article I, which is common to all of the Conventions states: "The High Contracting Parties undertake to respect and to ensure respect for the present Convention in all circumstances."93 Commentators have interpreted "to ensure respect" to mean that a government must not only oblige its own persounel to respect the Conventions but also other persons or entities within their range of authority or influence. ${ }^{94}$

The clearest exposition of the obligation to "ensure" rights by investigating and prosecuting disappearances is found in a recent decision of the Inter-American Court of Human Rights ${ }^{95}$ construing the American

92. Ireland v. United Kingdom, 25 Eur. Ct. H.R., (ser. A), I 239 (1978) (judgment) (emphasis added).

93. Geneva Convention I, supra note 61, art. 1, 6 U.S.T. at 3116, 75 U.N.T.S. at 32; Geneva Convention II, supra note 61, art. 1, 6 U.S.T. at 3220, 75 U.N.T.S. at 86; Geneva Convention III, supra note 61, art. 1, 6 U.S.T. at 3318, 75 U.N.T.S. at 136; Geneva Convention IV, supra note 61, art. 1, 6 U.S.T. at 3518, 75 U.N.T.S. at 288.

94. Murphy, Sanctions and Enforcement of the Humanitarian Law of the Four Geneva Conventions of 1949 and Geneva Protocol I of 1977, 103 MrL. L. Rev. 3, 25 (1984). Murphy also suggests that if a state is in violation of the Conventions, other states may be required to take action to ensure that the violating state henceforth respects the Conventions or risk becoming themselves violators. Id. In a similar vein, human rights supporters and refugee advocates have argued that the United States must respect the Conventions by not contributing to violations thereof in El Salvador. In Matter of Medina, I. \& N. Dec. No. 3078 (B.I.A. Oct. 7, 1988) (interim decision), an administrative tribunal rejected this argunient. The extent of any third-country obligation raises difficult questions that are beyond the scope of this Comment.

95. The Inter-American Court of Human Rights (Inter-American Court) was created as part of the enforceinent machinery of the American Convention on Human Rights, which entered into force in 1978. See American Convention, supra note 20, arts. 52-69. The American Convention, modeled in nany respects on the European Convention on Human Rights, establishes a list of 23 civil and pohtical rights to be "respected and ensured" by signatory governments. Id. arts. 3-25. The Inter-American Court is empowered to issue binding, adjudicatory opinions in cases brought before it involving countries that have made a separate declaration accepting the court's adjudicatory jurisdiction, either unconditionally or on a case-by-case basis. Id. art. 62 .

The American Convention also establishes the Inter-American Commission on Human Rights (Inter-American Commission) to receive and review complaints regarding governmental human rights violations. Id. arts. 34-51. Only the Commission or state parties to the Convention can refer a case to the Inter-American Court. Id. art. 61.1. Individual petitioners must bring their cases to the Commission, which then decides whether they are admissible. Id. arts. 44, 46-48. Once a case is declared admissible, the Commission requests information froin the government involved, and may conduct an on-site investigation or try to arrange a friendly settlement. Id. art. 48. The Cominission prepares a report, and within three months of the date the report is issued, either the Commission or the state involved may refer the case to the court. Id. arts. 50-51. For a full deseription, see $\mathrm{T}$. Buergenthal, R. Norris \& D. Shelton, Protecting human Rights in the Americas (2d ed. 1986). See generally Norris, The Individual Petition Procedure of the Inter-American System for the Protection of Human Rights, in GUIDE to INTERNaTIONAL HUMAN Rights Practice 108 (H. Hannum ed. 1984); Note, Recent Developments in International Organizations: First Contentious 
Convention on Human Rights. ${ }^{96}$ The Inter-American Court used the "ensure to all persons" language in article 1.1 of the American Convention $^{97}$ to find a sweeping obligation for governments to prevent, investigate, and, if necessary, prosecute those rehably accused of disappearances. The decision, Velasquez Rodriguez Case, ${ }^{98}$ the court's first contentious case under the compulsory jurisdiction provisions of the American Convention, provides further evidence of the emergence of the state obligation at issue. ${ }^{99}$

Velasquez concerned the arrest, torture and execution of a Honduran student activist by the Honduran military. Honduran authorities consistently demied any knowledge of his detention. ${ }^{100}$ The InterAmerican Commission's coinplaint, submitted to the court in April 1986, alleged violations of the rights to life, to humane treatment, and to personal liberty, as protected by the Convention. ${ }^{101}$

On July 29, 1988, the Inter-American Court rendered judgment in the Velasquez case. The court found the Honduran government guilty of violating the American Convention. ${ }^{102}$ As a preliminary inatter, the court rejected the Honduran government's assertion that internal remedies liad not been exhausted. Although the court acknowledged that remedies sucli as habeas corpus did exist in Honduran law, it found that

Cases Before the Inter-American Court of Human Rights, 3 AM. U.J. INr'L L. \& PoL'Y 283, 284-88 (1988) (authored by Neal S. Deodhar).

96. American Convention, supra note 20.

97. Article 1.1 reads:

The States Parties to this Convention undertake to respect the rights and freedoms recognized herein and to ensure to all persons subject to their jurisdiction the free and full exercise of those rights and freedoms, without any discrimination for reasons of race, color, sex, language, religion, political or other opinion, national or social origin, economic status, birtl, or any otler social condition.

Id. (empliasis added).

98. Velasquez Rodriguez Case, Inter-Am. Ct. H.R. 35, OAS/ser. L/N/III. 19, doc. 13, app. VI (1988).

99. Velasquez was heard witl two companion cases: Fairen Garbi \& Solis Corrales Case, Inter-Am. Ct. H.R., No. 7951 (1989), and Godinez Cruz Case, Inter-Am. Ct. H.R., No. 8097 (1989). Fairen Garbi \& Solis Corrales involved a Costa Rican couple who disappeared while driving through Honduras en route to Mexico. Godinez Cruz concerned a Honduran scliool teacher who disappeared in July 1982 after a witness saw him arrested by men in military uniforms. In all three cases, after requesting information from the Honduran government, the Commission declared the petitions adinissible and, pursuant to article 42 of its regulations, presumed the truth of the facts as stated in the petitions brought to the Commission by relatives of the disappeared individuals.

Velasquez, supra note 98, If 4; see also Note, supra note 95, at 289-90.

100. Velasquez, supra note 98, शा 10, 26, 159.

101. Id. If 1-2. Article 4 of the American Convention provides that every person has the right to have his or her life respected and that no one may be deprived of life arbitrarily. American Convention, supra note 20, art. 4.1. Article 5 protects physical, inental and moral integrity, and includes a prolibition aganist torture. Id. art. 5.1-5.2. Article 7 provides that no one may be arbitrarily deprived of plyysical liberty, and that anyone detained lias a right to know the cliarges against lier and to be brought before a competent judge or tribunal. Id. art. 7 .

102. Velasquez, supra note 98 , ๆIl $185,194$. 
in practice those remedies were ineffective "because the imprisonment was clandestime, formal requirements made them mapplicable in practice, the authorities against whom they were brought simply ignored them, or attorneys and judges were threatened and imtimidated by those authorities."103

In establishing the government's responsibility for Velasquez's disappearance, the court rehed on evidence presented by the Commission to establish that the Honduran government carried out or tolerated a pattern of disappearances between 1981 and 1984. Acknowledging that the disappearance of particular individuals may be difficult to prove, the court allowed the Commission to establish, first, that a policy or practice of disappearances occurred, and second, through circumstantial evidence and inference, that Velasquez's disappearance was part of this pattern. ${ }^{104}$ To establish the existence of a practice of disappearances, the Commission called former detainees and former members of the military as witnesses. ${ }^{105}$ The court found that 100 to 150 persons considered by Honduran officials to be dangerous to state security had disappeared in Honduras between 1981 and 1984 as a result of a systematic practice by those officials. ${ }^{106}$ Although no eyewitnesses came forward to testify, the Court did hear evidence from the victim's sister and an ex-soldier on Velasquez's abduction and killing. The court found that Velasquez's disappearance was part of the pattern of disappearances. ${ }^{107}$

Most importantly, the court found that the failure to guarantee the specific rights enumerated in the Convention is itself a violation of the state's obligations under article 1 of the American Convention. ${ }^{108}$ The opmion posits a state's duty to prevent, mvestigate, and pumsh any violation of the riglits recognized by the Convention. In addition, the state must attempt to restore the right violated, actually restore it if possible,

103. Id. I 80. The record in Velasquez showed that of three habeas corpus petitions filed on his behalf, one had been denied and the other two had been pending since 1981 and 1982, respectively. Id. If 74. In addition, his family had brought two criminal complaints against military officers. One complaint had been pending since 1982, and the other had been dismissed for lack of evidence. Id. The Honduran government alleged that, in spite of these results, domestic remedies had not been exhausted because several of the proceedings were still pending, while others could still be appealed through extraordinary writs (amparo, rehearing, and cassation). Id. I 75 .

104. Id. If 124.

105. Id. II $82-118$.

106. Id. ๆ 147.

107. Id. II 147-148. One of the alleged perpetrators, police agent Jose Isaias Vilorio, was mysteriously killed in Honduras, only days before he was scheduled to give testimony in the case. Id. ๆ 40.

108. Id. If 160-167, 182. The Court interpreted article 1 as determining when violations of substantive rights can give rise to state responsibility. "Any impairment of those rights [recognized in the Convention], which can be attributed under the rules of international law to the action or omission of any public authority, constitutes an act imputable to the State, which assumes responsibility in the terms provided by the Convention itself." Id. II 164. 
and provide compensation for damages. ${ }^{109}$

The court asserted that article 1's duty to "respect" rights implies a limitation on government power: a "negative" obligation not to interfere with the exercise of a riglit. But its obligation to "ensure" rights places an affirmative duty on the states parties. ${ }^{10}$ "This obligation implies the duty of the States Parties to organize the governmental apparatus and, in general, all the structures througl which public power is exercised, so that they are capable of juridically ensuring the free and full enjoyment of human rights." 111

This affirmative obligation is not fulfilled by the mere theoretical existence of a legal system to deal with complamts, but instead requires "governmental conduct which effectively ensures the free and full exercise of human rights." 112 So long as the government exhibits a lack of diligence in preventing or responding to the violation, the government has violated its affirmative duty-even if the responsible governmental organ or official lias violated domestic law or overstepped the bounds of authority, ${ }^{113}$ and even if the identity of the individual perpetrator is unknown or if the perpetrator is not a government agent. ${ }^{114}$ While recognizing that "[t]he duty to investigate, like the duty to prevent, is an obligation of means or conduct which is not breached merely because the investigation does not produce a satisfactory result," the court demanded that the duty be undertaken seriously. ${ }^{15}$

Applying this rule to the Velasquez case, the court found that the Honduran government liad breached its international obligation to guarantee the full and free exercise of human rights. ${ }^{16}$ The court pointed to the judicial system's failure to investigate the disappearance, compensate the victim's family, or punish the guilty. ${ }^{117}$ It criticized the Honduran government's imtial failure to imvestigate the allegations of disappearances im general and this allegation im particular. ${ }^{118}$ Further, it criticized the subsequent investigation because it was conducted by the military-

109. Velasquez states:

The State has a legal duty to take reasonable steps to prevent human rights violations and to use the ineans at its disposal to carry out a serious investigation of violations committed within its jurisdiction to identify those responsible, impose the appropriate punishmeut and ensure the victim adequate compensatiou.

Id. ๆ 174 .

110. Id. IT 165-166.

111. Id. $\mathbb{I} 166$.

112. Id. TI 166-167.

113. Id. | 170. But see RESTATEMENT, supra note 16, § 207 (state responsible for the acts of its officials only when they act within scope of or under color of authority).

114. Velasquez Rodriguez Case, supra note 98, 价 172-173.

115. Id. \ 177.

116. Id. \ 178 .

117. Id.

118. Id. ๆ 180. 
the party alleged to have perpetrated the crimes. ${ }^{119}$ The court ordered the Honduran government to pay compensation to the family of Velasquez. ${ }^{120}$ In sum, the court found an affirmative obligation under the "ensure and respect" clause to prevent, investigate, prosecute and punish grave violations of human rights. These ineasures are necessary to "ensure" human rights by deterring both current and future violators.

Nonetheless, the Velasquez decision leaves several unanswered questions. Among these are: whether the state's duty to act can be triggered by a simgle violation of the rights guaranteed by treaty; what showing of a violation is required; and what sort of remedy is appropriate if a violation is found. 121

Although the court relied on a pattern of violations as evidence of state involvement in Velasquez's disappearance, it did not himit its holding to cases where a consistent pattern of violations is shown. Thus, even a single violation might trigger the state's obligation to act, but it is difficult to tell what sort of evidence of a single violation would be sufficient. In cases of disappearance and paramilitary killing, it will often be impossible for the families of the victims to produce inore than a minimal amount of direct evidence. In cases of disappearances, the victim's fate and whereabouts will be, by definition, unknown. Further clarification of the case will depend on "information exclusively in the hands of the State party." 122 Yet, if no showing of any violation is required to trigger state responsibility, states might logically object that being held internationally liable for failure to investigate and prosecute will require them to spend time and resources looking into many unfounded allegations.

One solution would be to require the complainant to present prima facie evidence demonstrating that a grave violation of human rights has occurred and that the state has failed to take steps to investigate and prosecute. Sucl evidence may consist of direct witness testimony. The U.N. Human Rights Committee has found that "substantial witness testimony" is enougli to trigger the state's obligation to investigate. ${ }^{123}$

119. Id. ๆI 178-180.

120. Id. If $194-195$. Honduras was ordered to pay $\$ 150,000$ to the Velasquez family, Inter-Am. Ct. H.R., Press Release CDH-CP2/89 (Mar. 1989), and $\$ 130,000$ to that of Saul Godinez, InterAm. Ct. H.R., Press Release CDH-CP8/89 (July 21, 1989). The third case, that of Fairen Garbi and Solis Corrales, was dismissed for lack of sufficient evidence that the two had actually been stopped in Honduras. Telephone conversation with J. Mendez, attorney for plaintiffs (Jan. 7, 1990).

121. A fourth, and related, issue involves the contours of the state's obligation where there is no showing of state involvement in or condonation of the crime itself, but the state is derelict in investigating. This question is related to how far the state must go to comply with its obligation to "ensure" rights. As noted above, these issues raise complex legal and policy considerations beyond the scope of this Comment.

122. Irene Bleier Lewenhoff \& Rosa Valino de Bleier v. Uruguay, U.N. Hum. Rts. Comin. No. 30/1978, II 13.3, U.N. Doc. CCPR/C/OP/1 (1985) [hereinafter Bleier Case].

123. Id. For a description of the Human Rights Committee, see infra notes $142-51$ and accoinpanying text. 
However, in disappearance and death squad murder cases, such evidence may not exist. Where hittle direct evidence exists, parties should be permitted to submit circumstantial and inferential evidence sufficient to give rise to a presumption that the state is either supporting or tolerating disappearances or death squads. Such evidence could include the frequency of similar violations, the impunity with which the perpetrators act, the lack of any investigation-or evidence of stonewalling in an investigation-and evidence showing that the violation at issue is part of a pattern and practice initiated or tolerated by state authorities. ${ }^{124}$

International tribunals are familiar with the idea of a pattern or practice or "administrative practice," and should not have difficulty in applying it to disappearances and death squad murders. The European Court of Human Rights described an administrative practice as "an accunnulation of identical or analogous breaches which are sufficiently numerous and inter-connected to amount not merely to isolated incidents or exceptions but to a pattern or system."125 The European Court stated that such a pattern serves as constructive notice to higher governmental officials. ${ }^{126}$ Complainants can show an administrative practice by means of witnesses, survivors, reports of well-known human rights monitoring groups, and even press reports.

In addition to leaving unresolved these issues of evidentiary requirements, the Velasquez court hesitated to impose the sweeping remedy that seens to be implied by the language of its judgment. At the remedy stage, the court ordered only monetary compensation. ${ }^{127}$ The InterAmerican Commission, lawyers for the victims' families, and a group of international law experts acting as amici curiae had asked the court for much broader injunctive measures, including an injunction requiring Honduras to criminally prosecute those responsible for disappearances, restructure the security apparatus, publicly condemn the practice of dis-

124. See Brief Amicus Curiae for Association of the Bar of the City of New York in support of Velasquez Rodriguez at 23-26, Velasquez Rodriguez Case, supra note 98 (on file with author).

125. Ireland v. United Kingdom, 25 Eur. Ct. H.R., (ser. A), II 159 (1978) (judgment); see also The Greek Case, 1969 Y.B. Eur. Conv. on HuM. RTS. 511 (Eur. Comm'n on Huun. Rts.) (resolution); Second Greek Case, 1970 Y.B. EuR. CoNV. ON HUM. RTS. 132-34 (Eur. Comm'n on Huun. Rts.) (decision on admissibility); RESTATEMENT, supra note $16, \S 702$ (consistent pattern of gross violations is a separate violation under customary law); 22 U.S.C. $\$ 2304$ (1988) (U.S. law prohibiting military and security sales, or monetary aid to conntries whose governments engage in a "consistent pattern of gross violations of internationally recognized human rights").

126. Ireland v. United Kingdom, 25 Eur. Ct. H.R., (ser. A), I 159 (1978) (judgment). Recognizing the greater burden on governments unposed when an administrative practice is at issue, the European Court does not require plaintiffs to show exhaustion of domestic remedies in these cases. Id. If 157.

127. Velasquez Rodriguez Case, supra note 98, If 194. Article 63.1 of the American Convention, supra note 20, empowers the court to guarantee the victim the enjoyment of the affeeted right or hberty, repair the consequences of the breach, and assure payment of fair compensation to the injured party. Thus, the court has the power to order broad imjunctive measures. 
appearances, and pay homage to the victims. ${ }^{128}$

While the narrow remedy seems inconsistent with the broad characterization of the offense, it must be remennbered that this case was the first contentious case decided by the Inter-American Court of Human Rights. The Velasquez decision marks the leading edge in cases applying the "ensure and respect" language. ${ }^{129}$ If other cases are interpreted in the same fashion, the decision could have far-ranging consequences because other human rights treaties including the International Covenant and the European Convention have similar "ensure and respect" provisions. ${ }^{130}$ Thus the potential exists for such provisions to become the foundation for the duty of states to investigate and prosecute gross human rights violations, but the use of such language is still in its formative stages.

\section{Human Rights Treaties and the Right to a Remedy for Human Rights Violations}

\section{Right to a Remedy in International Instruments}

The multilateral human rights instruments that have entered into force since the founding of the United Nations in 1945 define the substantive rights of individuals vis-à-vis their own states. They represent commitments to the entire international commuinty by each state party. These commitments make human rights a proper subject for international concern and justify sanctions by other states, individually and collectively, for violations thereof. ${ }^{131}$ Because they focus on individual

128. Letter from Claudio Grossman and Juan E. Mendez, attorneys for the family of Saul Godinez, to the President of the Inter-American Court of Human Rights \#5 (Mar. 10, 1989) (discussing appropriate remedies for the client's family and for civil society); Brief of Twelve Jurists as Amici Curiae in support of Velasquez Rodriguez, Sobre la Reparacion de las Consecuencias de las Violaciones a los Derechos Humanos y la Justa Indemnizacion que Prescribe el Articulo 63.1 de la Convencion Americana de Derechos Humanos 17-18 (March 10, 1989) [hereinafter Reparacion] (both documents on file with author).

129. A majority of American countries still lave not accepted the compulsory jurisdiction of the court, and its meinbers may well have felt that ordering the full panoply of remedies would retard the process of adhesion to the American Convention's compulsory jurisdiction provisions. For a list of those countries that have (1) ratified the Convention and (2) specially accepted the court's compulsory jurisdiction, see infra note 205.

130. Article 1 of the European Convention for the Protection of Human Rights and Fundamental Freedoms, Nov. 4, 1950, 213 U.N.T.S. 222 [hereinafter European Convention] states that "[t]lie High Contracting Parties shall secure to everyone within their jurisdiction the rights and freedoms defined in Section I of this Convention." European Court jurisprudence, however, does not currently recognize article 1 as being capable of violation independently of the substantive rights enumerated in the other seetions of the Convention. Ireland v. United Kingdon, 25 Eur Ct. H.R., (ser. A), If 238 (1978) (judgment).

131. The International Court of Justiee has drawn a distinction between "the obligations of a State towards the international community as a whole" and those arising among individual states. Because all states have an interest in the former, they are "obligations erga omnes." Barcelona Traction, Light \& Power Co. (Belg. v. Spaim), 1970 I.C.J. 3, at 33. 
rights and not on state responsibilities, general human rights instruments do not refer directly to a state's obligation to investigate or prosecute under international law. However, they do recognize an individual's right to a reinedy when her rights have been violated. The Universal Declaration of Human Rights, ${ }^{132}$ the International Covenant on Civil and Political Rights, ${ }^{133}$ the American Convention on Human Rights, ${ }^{134}$ and the European Convention for the Protection of Human Rights and Fundamental Freedoins ${ }^{135}$ are among the instruments that recognize a right to a reinedy.

The Universal Declaration of Human Rights, the most accepted general articulation of recognized human rights, ${ }^{136}$ hists the right to a remedy in article 8: "Everyone has the right to an effective remedy by the coinpetent national tribunals for acts violating the fundamental rights granted him by the constitution or by law."137

The Universal Declaration extends a right to a remedy for violations of fundamental rights, presumably nicluding the right to life and freedonı from torture and arbitrary detention. The Declaration implies that the remedy nuust be individualized and adjudicatory. ${ }^{138}$ Thus, for example, mere payinent of ex gratia compensation without the right to civil or criminal adjudication in cases of torture or disappearance would arguably be insufficient under article 8 .

The International Covenant on Civil and Political Rights ${ }^{139}$ develops and specifies the civil and political rights enumerated in the Universal Declaration. It defines im article 2(3) the right to a remedy. ${ }^{140}$ The

132. See supra note 17.

133. See supra note 18.

134. See supra note 20.

135. See supra note 130.

136. RESTATEMENT, supra note $16, \S 702$ reporter's note 6 .

137. Universal Declaration, supra note 17. The Universal Declaration is not a treaty but a resolution adopted unanimously by the U.N. General Assembly in 1948. It is considered either an authoritative interpretation of the U.N. Charter or a statenent of customary law; in either case, at least its basic provisions are now considered binding on U.N. niember states. T. BUERGENTHAL, INTERNATIONAL HUMAN Rights 29-33 (1988); RESTATEMENT, supra note 16, § 701 reporter's notes 4,6 .

138. Eleanor Roosevelt, Chair of the U.N. Commission on Human Rights during the period when that body drafted the Universal Declaration, had einphasized that "appealing to a tribunal was an act of a judicial nature," not a nierely administrative one. Newman, Natural Justice, Due Process and the New International Covenants on Human Rights: Prospectus, PUBL1c LAW 274, 306 (Winter 1967) (citing U.N. Doc. E/CN.4/SR.109 (1949)).

139. International Covenant, supra note 18.

140. Article 2(3) reads:

Each State Party to the present Covenant undertakes:

(a) To ensure that any person whose rights or freedoms as herein recognized are violated shall have an effective remedy, notwithstanding that the violation has been committed by persons acting in an official capacity;

(b) To ensure that any person claiming such a remedy shall have his right thereto determined by coinpetent judicial, administrative or legislative authorities, or by any other 
drafting history of the Covenant reveals that the Commission on Human Rights was concerned with ensuring accountability of government authorities for violations, especially by ruling out the defenses of sovereign immunity or following superior orders. ${ }^{141}$ The drafters therefore specified, in article $2(3)(a)$, that the right to a reniedy does extend to violations by government officials.

In addition to the text of article 2(3) of the International Covenant, which establishes an international obhigation on the part of state parties to provide remedies within the domestic legal systen, the implenientation provisions of the Covenant itself contain a procedure whereby individuals claiming a violation of the Covenant's provisions nuay bring a coniplaint against a state. However, that procedure only applies if the state has specifically accepted the jurisdiction of the U.N. Human Rights Committee by signing the Optional Protocol to the Covenant. ${ }^{142}$ During the drafting of the Convention, some states wanted to strengthen the affirmative obligation on the part of government authorities to prosecute violations. The Philippine representative proposed adding the sentence "Violators shall be swiftly brought to the law, especially when they are public officials," 143 making explicit a governnent obhigation to prosecute those violating human rights. Although the proposal was defeated without discussion, the Philippine representative stressed that the defeat "should not be taken to mean that the Commission was indifferent to the

competent authority provided for by the legal system of the State, and to develop the possibilities of judicial remedy;

(c) To ensure that the competent authorities shall enforce such remedies when granted.

Id. The rights protected are those enumerated in the Covenant itself. While the Covenant provides for a broader range of adjudicatory mechanisms than does the Universal Declaration, its focus is still on adjudication of individual rights, preferably by a judicial process.

141. Schachter, The Obligation to Implement the Covenant in Domestic Law, in THE INTERNATIONAL BILL of RIGHTS, supra note 90, at 326; 10 U.N. GAOR Annex (Agenda Item 28) ch. V, I 15, U.N. Doc. A/2929 (1955).

142. Optional Protocol to the International Covenant on Civil and Political Rights, Dec. 19, 1966, G.A. Res. 2200 (XXI), 21 U.N. GAOR Supp. (No. 16) at 59 arts. 1-2, U.N. Doc. A/6316 (1967), reprinted in 6 I.L.M. 383 (1967) [heremafter Optional Protocol]. The Human Rights Committee is composed of 18 experts, elected for four-year terms by state parties to the Covenant, who serve in their personal capacities. It is not a judicial body, but rather considers individual complaints submitted to it and forwards its views on the complaint to the state party concerned and to the individual. The Committee's final report is made public. CENTRE FOR HuMAN RIGHTS, United Nations Office at Geneva, Fact Sheet No. 1: Human Rights Machinery 12-14 (1987). See table at note 205 for number of signatory states.

143. 6 U.N. Comm'n on Hum. Rts. (195th mtg.), ๆ24, U.N. Doc. E/CN.4/SR.195 (1950). The proposal was justified on the following basis: "This addition places upon the State the responsibility of taking the mitiative in the investigation and prosecution of abusive acts. The victim is too often under the influence of fear, so the Government itself should act with energy to bring the criminals swiftly to justice. The last words, 'especially when they are pnblic officials', are designed particularly to curb abuse of power by such government agents." 6 U.N. Comm'n on Hum. Rts (365th mtg.) at 15, U.N. Doc. E/CN.4/365 (1950); see also M. BossuYT, Guide to THE "TravauX Preparatoires' of the International Covenant on Civil and Political Rights 65 (1987). 
fate of violators of human rights."144 -

Despite the defeat of the Philippine proposal, the Human Rights Committee has interpreted the obligation to provide a reinedy to include an obligation to investigate and prosecute violations of the Convention. Just as the Inter-American Court of Human Rights in Velasquez found an obligation to investigate and prosecute human rights violators by combining the general "ensure and respect" language of article 1.1 of the American Convention with the substantive prohibitions on torture and arbitrary killing, the Human Rights Committee has found the same obligation by combining the general right to a remedy with the prohibitions agamst torture in article 7 of the Covenant. In a comment on article 7, the Committee read this article together with article 2 to conclude that "States must ensure an effective protection through some machinery of control. Complaints about ill-treatment must be imvestigated effectively by competent authorities. Those found guilty inust be held responsible, and the alleged victims must themselves have effective remedies at their disposal, including the right to obtain compensation."145

The Human Rights Committee underscored this imterpretation in findings in several cases concerning arbitrary arrests, torture, and disappearances in Uruguay during the late 1970s. In the case of Eduardo Bleier, ${ }^{146}$ among others, the Committee found that the state had a duty to investigate and-if necessary-prosecute, as well as pay reparation. Bleier was arrested without a court order in October 1975, and his detention was unacknowledged by the authorities, although his name did appear for a time on a hist of military prisoners. ${ }^{147}$ The Uruguayan governinent iguored the Committee's requests for a "thorough inquiry."148 The Committee found that "[i]t is implicit in article 4(2) of the Optional Protocol that the State party has the duty to investigate in good faith all allegations of violation of the Covenant made agamst it and its authorities." 149 The Committee reviewed the evidence revealing breaches of articles 7 (torture), 9 (arbitrary detention), and 10(1) (humane treatment for prisoners), and possibly article 6 (right to life). ${ }^{150}$ It called on the Uruguayan government to

take effective steps (i) to establish what has happened to Eduardo Bleier

144. 6 U.N. Comm'n on Hum. Rts. (195th mtg.) at If 25, U.N. Doc. E/CN.4/SR.195 (1950) (statement of Mr. Mendez).

145. 37 U.N. GAOR Supp. (No. 40) at 94, U.N. Doc. No. A/37/40 (1982).

146. Bleier Case, supra note 122.

147. Id. at 109 ๆ 2.2 .

148. Id. at $112 \Uparrow 13.2$.

149. Id. at 112 ๆ 13.3. Article 4(2) of the Optional Protocol states: "Within six inonths, the receiving State shall submit to the Committee written explanations or statenents clarifying the matter and the remedy, if any, that may have been taken by that State." Optional Protocol, supra note 142 .

150. Bleier Case, supra note 122, at 109-11. 
since October 1975; to bring to justice any persons found to be responsible for his death, disappearance or ill-treatment; and to pay compensation to him or his family for any injury which he has suffered; and (ii) to ensure that similar violations do not occur in the future. ${ }^{151}$

Thus, the body charged with interpreting the Covenant has interpreted the right to a reinedy to include an obligation to investigate and prosecute as well as to provide coinpensation.

Similarly, the Inter-American Commission on Human Rights lias interpreted "riglit to a reinedy" language in the American Convention to include the obligation to investigate and prosecute. Article 25 of the American Convention provides for the right to a relnedy. ${ }^{152}$ The Coinmission has repeatedly called for investigation of the facts and pumishment of the responsible individuals in cases of torture or disappearance. ${ }^{153}$

Finally, the European Court of Human Rights has also interpreted the "riglit to a reinedy" language of the European Convention for the Protection of Human Rights and Fundamental Freedoins ${ }^{154}$ to include the obligation to investigate and prosecute. Article 13 of the European Convention provides that "[e]veryone wliose riglits and freedoins as set fortl in this Convention are violated shall lave an effective remedy before a national authority notwithstanding that the violation lias been committed by persons acting in an official capacity." 155

151. Id. at 112 I 15 (emphasis added). The Bleier case was not an isolated instance of the Commission's concern. In the case of Alberto Grille Motta, the Commission found that Uruguay "has adduced no evidence that these allegations [of arbitrary detention, etc.] have been duly investigated .... A refutation of these allegations in general terms is not sufficient. The State party should have investigated the allegations in accordance with its laws and its obhgations under the Covenant and the Optional Protocol and brought to justice those found to be responsible." U.N. Hum. Rts. Comm'n No. 11/1977, Alberto Grille Motta, Selected Decisions 56-57 I 14; see also U.N. Hum. Rts. Comm'n No. 4/1977, William Torres Ramirez, Selected Decisions 51 १ 16; U.N. Hum. Rts. Comm'n No. 9/1977, Edgardo Dante Santullo Valcada, Selected Decisions 44 ๆ 11 (supporting the duty to investigate and prosecute).

152. Article $25(1)$ provides that "[e]veryone has a right to simple and prompt recourse . . . against acts that violate his fundamental rights recognized by the constitution or laws of the state concerned or by this Convention." American Convention, supra note 20. This Convention thus follows the approach of the Universal Declaration. See supra text accoinpanying notes 137-38.

153. See, e.g., Case 7821, Inter-Am. Ct. H.R. 86, 87, OAE/ser.L./V/II.57, doc. 6 rev. 1 (1982) (disappearance); Case 6586 Infer-Am. Ct. H.R. 91, OEA/ser.L./V/II/61, doc. 22 rev. 1 (1983), at 93 (torture, arbitrary arrest). The Inter-American Court of Human Rights, although not relying on this provision, has interpreted the American Convention to require investigation and prosecution of human rights violations. See supra text accompanying notes 96-99.

154. European Convention, supra note 130.

155. Id. art. 13. Commentators criticize this provision as ambiguous. See, eg., J.E.S. Fawcett, Application of the European Convention on Human Rights 289 (1987) ("Article 13 is an unsatisfactory Article, difficult ... to construe"); F. CASTBERG, THE EuropEAN CONVENTION ON HUMAN RIGHTS 157 (1974) (terms of the provision are puzzling). Part of the ambiguity stems from confusion over whether the article requires a remedy only when the Committee of Ministers, the Human Rights Court, or a domestic court (in countries where the Convention is directly applicable as domestic law) has alrcady found a violation of the Convention- 
The European Court has on at least one occasion adopted a liberal construction of the remedy provision. In the Klass case, ${ }^{156}$ the Court held that article 13 requires the state to ensure a remedy under national authority in order to have the claim (of a violation of the Convention) decided and, if appropriate, to obtain redress. ${ }^{157}$ Thus, in the case of a disappearance, the remedy would include a determination of the claim that a disappearance had oceurred as well as redress for the violation.

In sum, the right to a remedy is common to inajor human rights imstruments. ${ }^{158}$ It encompasses the requirement of an adjudicatory system to hear and decide on complaints, and the availability of redress once a violation is found. The question remains, however, of what kind of redress is implied once a disappearance or death squad killing has occurred.

\section{The Scope of Remedy Required by Human Rights Instruments}

While many instruments provide for a right to a remedy, few commentaries or cases on "right to a remedy" provisions explicate the content of that right. However, cases dealing with exhaustion of domestic remedies do elaborate on appropriate remedies under international law. ${ }^{159}$ The law of exhaustion of remedies holds that individuals must have exhausted their avenues of redress in domestic legal systems before turning to international adjudication. ${ }^{160}$ It presupposes the existence of state-provided remedies, and is the logical counterpart to the right to a remedy under international law. ${ }^{161}$

In general, remedies must be botll effective and adequate. While the effectiveness of a given remedy will vary depending on the specific conditions, the jurisprudence on exhaustion of remedies helps to determine when a remedy is effective. Remedies are not effective, for example,

the approach favored by Professors Fawcett and Castberg, J.E.S. FAwceTT, supra, at 291-92, F. CASTBERG, supra, at 158-or whether part of the remedy is precisely a determination of whether or not there has been a violation. If the former view is adopted, the scope of the right is very limited.

156. Case of Klass and Others (F.R.G.), 28 Eur. Ct. H.R. (ser. A) (1978) (German nationals brought suit against their government for allegedly violating the Convention by enacting a particular surveillance law).

157. Id. $\Uparrow 64$.

158. In addition to the provisions of these treaties, the Torture Convention, supra note 62 , also contains provisions requiring a remedy for violations. See supra notes 77-80 and accompanying text.

159. The requirement of exhaustion of domestic remedies predates imternational concern with human rights: it was a part of the traditional law of diplomatic protection. The rule arose because of the heavy political overtones of diplomatic protection cases, in which one state brought a claim against another based on an mjury to its own national. The rule gave the state an opportunity to remedy the wrong within its own legal system in order to reduce interstate tensions, and to provide for prompt, peaceful dispute resolution. A. TRINDADE, The Application of the Rule of EXHAUSTION OF LOCAL REMEDIES IN INTERNATIONAL LAW 11-12 (1983).

160. Z. NEDJAT, HuMAN RightS UNDER THE EUROPEAN CONVENTION 15-16 (1978).

161. A. TRINDADE, supra note 159 , at 56. 
when the complainant is prevented from having recourse to them, domestic laws do not afford adequate rehef, courts are not independent, or the proceedings take too long. ${ }^{162}$ The basic criterion is whether the remedy gives satisfaction to the claimant. ${ }^{163}$ In addition to being effective, a remedy must also be adequate given the nature of the complaint. ${ }^{164}$

While remedies must be both adequate and effective, the texts of the international human rights instruments do not set out any specific remedies. Professor Schachter, writing on article 2(3) of the International Covenant, suggests that "undoing, repairing and compensating for violations" 165 constitute appropriate remedies. These probably refer to, at the least, injunctive relief, restoring the victim to his previous position if possible, and monetary compensation. However, other remedial action under domestic law may also be appropriate. Thus, "cease and desist" orders, restructuring of the police or armed forces responsible for the violation, or court-ordered investigation are all feasible remedies. ${ }^{166}$

What kind of remedy would be both effective and adequate in the case of a forcible disappearance or extrajudicial killing? The traditional remedy for those detained by the government is a writ of habeas corpus. ${ }^{167}$ Habeas writs serve to establish whether or not a violation has occurred, and to remedy it by producing the person detained. A version of habeas exists as part of the laws of many countries, including the Latin American countries that are the focus of this Comment. ${ }^{168}$ In cases of disappearance, however, habeas corpus has not been an effective reinedy,

162. Id. at 72; see also Norris, Bringing Human Rights Petitions Before the Inter-American Commission, 20 Santa Clara L. Rev. 733, 742 (1980). Norris adds a consistent pattern of governmental interference with due process of law or of gross violations of fundamental human rights as circumstances likely to relieve the coinplainant of the exhaustion requirement.

163. A. TR1NDADE, supra note 159 , at 74 .

164. Donnelly v. United Kingdom, 1976 Y.B. Eur. Conv. on Hum. RTs. (Eur. Comm'n on Hum. Rts.) 84, 234-36.

165. Schachter, supra note 141 , at 325 .

166. Id. In many countries, civil suits and criminal prosecutions are intertwined, with the victim playing an active role in the criminal case. In these countries, criminal prosecution is even more clearly part of the victim's remedy. See, e.g., Klem v. Superior Court, 198 Cal. App. 3d 894, 900, 244 Cal. Rptr. 226, 228 (1988) (citing article 7 of the Geneva (Switz.) Code of Criminal Procedure as providing that a civil action for damages caused by crime may be brought at the same time and before the same court as criminal action). Argentine law also intertwines civil and criminal remedies. See supra note 37.

167. Habeas corpus ad subjiciendum is the most common form of habeas writ and is directed to the person detaining another, coinmanding him to produce the person detained. BLACK's LAW DICTIONARY 638 (5th ed. 1979).

168. See, e.g., El SALVADOR CONST. art. 164 ("Every person has the right of habeas corpus before the Supreme Court of Justice . . . whenever any authority or individual illegally restricts his freedom."), reprinted in 4 A. PeAsley, Constitutions of Nations 546 (3d ed. 1970); URuguay CONST. art. 17 ("In the event of unlawful detention, the interested party or any other person may apply to the competent judge for a writ of habeas corpus."), reprinted in A. PEASLEY, supra, at 1220. 
since unany countries simply ignore it. In Argentina, habeas petitions by relatives of the disappeared went unanswered or were rejected. ${ }^{169}$ In Honduras, the relatives of Manfredo Velasquez filed three writs of habeas corpus on his behalf, but to no avail. ${ }^{170}$ Most habeas petitions in Honduras have been similarly ineffectual. ${ }^{171}$ Communications to the U.N. Human Rights Committee reveal that the habeas corpus writ inet the same fate in Uruguay. ${ }^{172}$ Petitioning for a writ of habeas corpus is therefore an ineffective remedy in those countries that countenance the use of disappearances and death squad killings.

The European Commission has addressed the question of what constitutes an adequate remedy in cases of official torture or ill-treatment. Where a state.has taken reasonable steps to comply with its international huinan rights obligations, but mistreatment of an individual nonetheless occurs, the Commission found that compensation generally will constitute an adequate remedy. ${ }^{173}$ The state inust put into place a system that prevents, as far as possible, the occurrence or repetition of the acts in question. ${ }^{174}$ Where the state has no such system, compensation will not be sufficient. Thus, by definition, if state authorities pursue a policy or administrative practice authorizing or tolerating conduct in violation of articles of the Convention, compensation alone will not be adequate.

Monetary compensation, by analogy, is not an adequate remedy in disappearance or death squad cases, which almost always involve statesanctioned administrative practices. Compensation, by focusing exclusively on post-violation redress, minimizes the adjudicatory aspect of the right to a remedy. Even as a measure of redress, compensation is insufficient. Investigation and recounting the victim's fate are also vital to eliminate the uncertainty and anguish of the families. ${ }^{175}$ Prosecution constitutes an important avenue for recounting because it puts the state's resources at the service of truth-telling and because it identifies those

169. Osiel, supra note 29 , at 140 .

170. Velasquez Rodriguez Case, supra note 98, I 74. The court in Velasquez found that the habeas remedy was ineffective for several possible reasons: the imprisonment was clandestine; formal requirements such as stating the place of detention and the responsible authority made the remedy inapplicable in practice; the authorities against whom it was brought simply ignored it; or attorneys and judges were threatened and intimidated by those authorities. Id. ๆ 80 .

171. Id. ๆ 76.

172. See, e.g., Bleier Case, supra note 122, at 110 \{ 2.5 (habeas corpus and similar remedies irrelevant where penal procedures not followed in practice).

173. Donnelly v. United Kingdoin, 1976 Y.B. Eur. Conv. on HUM. RTs. (Eur. Comm'n on Hum. Rts.) 84, 234-36.

174. Id.

175. For example, Larry Weschler found that truth-telling was the primary demand of the families of disappeared persons and torture victins in Uruguay. Weschler, supra note $44, \mathrm{pt} .2$ at 95 (April 10, 1989) ("IO]nce there was a true accounting, nobody had any interest in anyone else's going to jail."). The distinctive nature of disappearances as human rights violations is their ability to affect entire families, who cannot rest until they know whether their loved one is dead or alive. 
responsible for the disappearance or murder. Furthermore, criminal prosecution in many countries involves the victim much more than it does in the United States, and civil and criminal penalties are closely intertwined. In these countries, criminal prosecution is essential to any civil suit by the victims or their families against the perpetrators. ${ }^{176}$ Prosecution is also a preventative measure against future repression: mdeed, one theory of modern punishment is founded on the deterrent effect of criminal prosecution and punishment. ${ }^{177}$

Redressing grave human rights violations may also require reorganization of the state apparatus to prevent a recurrence of the violation. This may mclude disbanding or reforming military or pohice structures, and dismissing or withholding the pension rights of those in charge. The disbanding of a repressive security apparatus and dismissal from office of mdividuals involved in violations will help ease the fear of victims and their families that they could again be targeted. ${ }^{178}$

If combined with these remedies, monetary compensation may constitute an important form of post-adjudicatory redress. Several international conventions provide a right to compensation for the victim or her family in cases of human rights violations. ${ }^{179}$ In the case of a disappearance, such compensation must include payment to the family not only for the loss of their loved ones, but also for the pain and suffering caused by continumg uncertainty about the loved one's fate. If, as is rarely the case, the victim should reappear, coinpensation must include rehabilitation. ${ }^{180}$ In addition to compensation by the state, the victim or her fainily may seek coinpensation from the individuals or institutions

176. See supra note 166.

177. W. LAFAVE \& A. SCOTT, CRIMINAL LAW 24 (1986) (the punishment of a criminal serves to deter others from committing such crimes).

178. Family members of those disappeared have often themselves become the targets of government repression, falling victim to disappearances or death squad killings. This is especially likely if they have protested the disappearance of their loved one. For example, Rosario Cuevas de Godoy, wife of a disappeared Guatemalan trade unionist and active im a group of family members of the disappeared, was killed along with her three-year-old son by a death squad in Guatemala in 1985. AMERICAS WATCH COMM., THE GROUP FOR MUTUAL SUPPORT 1984-85 (1985) [hereinafter AW, MUTUAL SUPPORT].

179. See, e.g., Torture Convention, supra note 62, art. 14 (enforceable right to fair and adequate compensation for victims of torture and their dependents); International Covenant, supra note 18, art. 9(5) (enforceable right to compensation for victims of unlawful arrest or detention); American Convention, supra note 20, art. 63(1) (payment of fair compensation to anyone affected by violation of a right proteeted by the Convention, among other remedies); European Convention, supra note 130, art. 5(5) (compensation for unlawful arrest or detention). For a discussion of a model compensation program for victinıs, see Lutz, After the Elections: Compensating Victims of Human Rights Abuses, in New DiREctions in Human Rights 195 (E. Lutz, H. Hannum \& K. Burke eds. 1989).

180. Article 14 of the Torture Convention, supra note 62 , specifically mentions rehabilitation as the state's responsibility. 
involved; ${ }^{181}$ one example might be cuts in the military budget to establish a fund for victims' coinpensation.

In sum, to be both adequate and effective, a remedy inust include investigation and prosecution or other state-initiated action against those responsible for the grave human rights violations at issue. Human rights instruments, especially the regional treaties, recognize a broad view of remedy and provide the most developed enforcement machinery. Article 50 of the European Convention on Human Rights, describing the powers of the Court of Human Rights, refers to the need to "afford just satisfaction to the injured party." 182 The American Convention is even broader, einpowering the court to ensure the victini's enjoyment of the affected right or freedom, to repair the consequences of the violation of the victini's rights, and to assure payment of fair compensation to the victini or her family. ${ }^{183}$ Thus, the regional treaties, as well as more general international instruments, conteinplate a view of reinedy that encoinpasses investigation and prosecution.

\section{Is the Treaty-Based Obligation Derogable? Amnesties Under International Law}

The first three Sections of this Part have argued for the existence of treaty-based state obligations to investigate grave human rights violations and to take action agaimst those responsible. Because international law requires investigation and prosecution, a state may not ignore its obligations by asserting an obligation to comply with conflicting doinestic legislation or practice. ${ }^{184}$ Further, the obligation is imiposed on the state, not the government; therefore, a change in goveruments does not relieve the state of its commitments under international law. ${ }^{185}$ Thus, a state could

181. See Lutz, supra note 179 , at 206 . However, as Lutz points out, many victims will be wary of suing the individual perpetrators for fear of reprisals, or because evidence of individual participation is usually hard to obtam. Id. at 205.

182. European Convention, supra note 130, art. 50.

183. American Convention, supra note 20, art. 63. The original draft of the Convention called only for the court to determine the "amount of compensation to be paid." By the time the Convention was finalized, the compensation aspect of the court's powers had been relegated to third place in the list of appropriate remedies. Reparacion, supra uote 128, at 9-10; see also Schachter, supra note 141 (scope of available remedies under the International Covenant).

184. Vienna Convention, supra note 56 , art. 27 ("A party may not imvoke the provisions of its internal law as justification for its failure to perform a treaty").

185. M. JANIS, AN INTRODUCTION To INTERNATIONAL LAw 128 (1988) ("States, not their governments, are subjects of international law"). As the Velasquez court stated:

According to the principle of the continuity of the State in international law, responsibility exists both independently of changes of government over a period of time and continuously from the time of the act which creates responsibility to the time when the act is declared illegal. The foregoing is also valid in the area of human rights although, from an ethical or political point of view, the attitude of the new government inay be much more respectful of those rights than that of the government in power when the violations occurred.

Velasquez Rodriguez Case, supra note 98, I 184. 
only escape its obligation to investigate and prosecute if the failure to do so fell within an applicable exception of the luuman rights treaties.

In some cases, the states adopted the human rights treaties in question only after inost or all of the violations had been committed. In Argentina and Uruguay, for example, incoming civilian governments sigued international luuman rights instruments to syinbolize their break with the repressive past. While the incoming government is not responsible under these instruments for violations that occurred before signature, it is bound to coinply with the obligation in the imstrument to investigate and prosecute. Thus, while claims of torture, disappearance, or suminary execution inay not theinselves be subject to the jurisdiction of the Inter-American Court, a claim that the failure to fully imvestigate and prosecute violates the American Convention is within the court's coinpetence. ${ }^{186}$

Several Latin American countries have passed laws granting amnesty to members of the security forces. ${ }^{187}$ These laws preclude criminal prosecution and civil remedies for grave human rights violations including torture, suminary execution, and disappearances. ${ }^{188}$ These

186. The Inter-American Court of Human Rights has established that, under the American Convention, the state has a legal duty to investigate, impose appropriate punishment, and ensure that the victim receives adequate compensation. See supra notes 95-99 and accompanying text; Velasquez Rodriguez Case, supra note 98, II 174.

187. In Argentina and Uruguay, successor governments passed laws exonerating members of the military. By precluding criminal jurisdiction, the amnesty laws also prevented victims and their families from instituting civil actions against the perpetrators of human rights violations. For example, under Uruguayan law, if the state is precluded from prosecuting, civil remedies in courts of ordinary jnrisdiction are also foreclosed. AW, CHALLENGING IMPUNITY, supra note 44, at 21-22. In Argentina, serious felomies are considered offenses against both the individual victim and the society, and civil damages are to be sought during the criminal prosecution. Mignone, Estlund \& Issacharoff, supra note 37 , at $123 \mathrm{n} .17$. In these cases an ainnesty law precluding the state's ability to prosecute will also effectively deny a civil remedy to victims of human rights violations.

In Guatemala and El Salvador, amnesty laws that passed in the context of regional peace efforts benefited few civilians, but have been used by the security forces to avoid criminal and civil proceedings. Guateinala's Decree Number $32-88$ of July 4, 1988, provides annesty to those persons who committed political crimes and related common crimes against the internal political order, pnblic order, and social tranquility before June 23, 1988. Diario de Centroamerica, July 8, 1988, at 1, col. 4. El Salvador's amnesty decree of October 28, 1987, resulted in the dismissal of indictments against soldiers and military officers for massacring $n_{p}$ to 74 people near Las Hojas, Sonsonate. Salvadoran human rights groups have appealed to the Inter-American Commission to instruct the Salvadoran government to prosecute those culpable and to pay coinpensation, as well as to seek an advisory opinion froun the Inter-American Court on the relationship between amnesty and human rights law. Petition to the Inter-American Commission on Human Rights for the Victims and Families of the Victims of the Massacre of Las Hojas, Sonsonate, El Salvador, at 11, 17 (Jan. 17, 1989) (on file with author).

188. See supra notes 30-55 and accoinpanying text. Professor Robert K. Goldman argues that the amnesties decreed by Latin American governments are "moral and legal perversions of the . . . concepts of amnesty and pardon." R.K. Goldınan, Amnesty Laws, International Law and the American Convention on Human Rights, THE LAw Group DoCKET, Summer 1989, at 1, 3.

The State's right to abolish or forget the crimes of those who have infracted its sovereignty by rebellion or otherwise flows from the role of the State as the victim. Thus, the State inay 
"amnesties" can only be legal under international law if the obhigation to investigate and take action against gross violators of human rights is derogable-that is, if it can be overcome by domestic considerations.

This Section argues that for the grave human rights violations at issue in this Comment-summary execution, torture, disappearancedomestic amnesty laws are not justifiable on either legal or policy grounds. Legally, an amnesty law must fit within an applicable exception to the normally bimding nature of human rights treaty provisions im order to be derogable. From a policy standpoint, the absolute nature of the underlying right becomes meaningless if the state need take no action agamst those who violate it.

The International Covenant on Civil and Political Rights, and the European and American Conventions on Human Rights all contain provisions permittimg derogation from some, but not all, human rights obhgations in certam circumstances. The most common exception is for conditions of "public emergency." 189 Article 4 of the International Covenant states:

In time of public emergency which threatens the life of the nation and the existence of which is officially proclaimed, the States Parties to the present Covenant may take measures derogating from their obligations ... to the extent strictly required by the exigencies of the situation, provided that such measures are not imconsistent with their other obligations under international law .... ${ }^{190}$

The European Court of Human Rights has interpreted almost identical language to mean that the danger must be actual or imminent to qualify as a public emergency, the effects must involve the whole nation, and the danger must threaten the contimuance of the organized life of the commumity. In addition, "[t]he crisis or danger must be exceptional, in that the normal measures or restrictions permitted by the Convention for the maintenance of public safety, health and order, are plainly madequate."191

Although the state's determination of the danger is subject to international scrutmy, it is up to each state initially to decide whether there is an emergency threatening the life of the nation, what measures are necessary to cope with the emergency, whether any such measures derogate

find that its interests such as national reconciliation are best served by an amnesty. However, the State should not have the prerogative to abolish or forget its own crimes or those of its agents committed against its citizens. If the right to abolish or forget such crimes exists, then it belongs only to the victims theinselves.

Id. (einphasis in original).

189. International Covenant, supra note 18, art. 4(1); European Convention, supra note 130, art. 15; American Convention, supra note 20, art. 27(1).

190. International Covenant, supra note 18 , art. $4(1)$.

191. The Greek Case, 1969 Y.B. Eur. Conv. ON HuM. RTs. 511, If 153 (Eur. Comm'n on Huin. Rts.) (resolution). 
from obligations under human rights imstruments, and whether tlie measures are strictly required. However, the state must inform other treaty parties of the reasons for the emergency and the range of rights affected, so that other states may decide whether to cliallenge the legality of the derogations. ${ }^{192}$

Given the fragility of the new civilian governments and the strength of the military threat in the countries of the Southern Cone, a plausible argument can be made that a public emergency requiring derogation of some rights did exist when those countries passed amnesty decrees. For example, the Argentime due obedience law ${ }^{193}$ was passed sliortly after an attempted military rebellion during Easter 1987, in which the rest of the military refused to move agaimst the mutmeers, prompting a governmental crisis. ${ }^{194}$ It is even possible, althougl unlikely, that such derogation was "strictly required" by the exigencies of the immediate military threat, and that less drastic alternatives were not available.

However, the public emergency exception is limited. First, the Covenant and the European and American Conventions only permit derogations where such measures are not imconsistent with otlier obligations under mternational law. ${ }^{195}$ Some imternational mstruinents permit no derogation at all. Thus, for example, article 2(3) of the Torture Convention specifically prohibits derogation of the treaty's provisions under any circumstances. ${ }^{196}$ Similarly, the obligation to searcli for persons alleged to have committed "grave breaclies" of the Geneva Conventions and bring them before a court apphes even during war-an extreme form of

192. International Covenant, supra note 18, art. 4(3); European Convention, supra note 130, art. 15(3); American Convention, supra note 20, art. 27(3).

193. See supra notes $30-43$ and accompanying text for a description of the context of the law.

194. AW, ARgentina, supra note 30, at 68. The mutineers, led by Colonel Aldo Rico, demanded an amnesty law as well as the dismissal of all active-duty generals. Although the rebellion was eventually put down with the help of some 50,000 civilians who surrounded the plotters, President Alfonsin gave in to some of their demands. Id. at 68-69. In Uruguay, President Sanguinetti and other politicians played on fears of a new military takeover or of "Argentine-style instability" to defeat the anti-amnesty referendurn. Weschler, supra note 44, pt.2 at 87-88 (Apr. 10, 1989). Even in Central America, amnesties benefitting the military were passed ostensibly as part of a larger process of social pacification.

195. Schreuer, Derogation of Human Rights in Situations of Public Emergency: The Experience of the European Convention on Human Rights, 9 YALE J. OF WORLD PUB. ORD. 113, 129 (1982); Buergenthal, supra note 90 , at 82.

196. Torture Convention, supra note 62, art. 2(2)-(3). In Argentina, the due obedience law providing amnesty for most military officers was passed after Argentima signed both the International Covenant and the Torture Convention, but a few days before the Torture Convention entered into effect. Technically, therefore, the Convention was not in effect when the law was passed and it does not apply. Nevertheless, article 18 of the Vienna Convention, supra note 56, provides that where a treaty las been signed but has not yet entered into force, signatory states may not take action that would defeat the object and purpose of the treaty. Because the purpose of the Torture Convention is to prevent and punish torture and to bring the guilty to justice, the Argentine government has breached its imternational obhgations by exempting all but a few military officers froin prosecution. 
public emergency. ${ }^{197}$ Thus, if an obligation to investigate and prosecute violators of fundamental human rights derives from the state's obligation under these penal conventions, that duty remains despite the existence of a public emergency. Further, an infringement of these other international obligations would also violate the derogability provisions themselves, thus subjecting the state to the enforcement machinery of both the penal conventions and the Covenant or regional conventions. ${ }^{198}$

Second, while some treaties consider some rights derogable in times of public emergency, other rights are always nonderogable. A measure that eliminated a derogable right would be imvalid if it also undermined a nonderogable right. While neither the right to a remedy nor the state's obligation to ensure rights is among the nonderogable rights, the right to life and the prohibition against torture are always nonderogable. ${ }^{199}$ Derogation from the duty to provide a remedy or to ensure these nonderogable rights would arguably violate the treaties involved, smce it would conflict with other obligations under international law.

This view is supported by the policy reasons for making some rights nonderogable. Certain actions, such as torture, are prohibited by a nonderogable right because the actions are so repuguant to the international community that no circumstances, no matter how exigent, can justify them. A necessary corollary of the nonderogability of such rights is that the actions are always subject to sanction and remedy. Thus, when these underlying rights are at issue, the right to state-imposed sanctions and remedies must also be considered nonderogable. The nonderogable nature of the underlying right would be meaningless if the state was required to take no action against those who violate it.

The mternational community is beginning to recognize this view on the limits of aninesty laws. A United Nations special rapporteur, im a 1985 report on aninesty provisions, ${ }^{200}$ suggested that torture, forced disappearances, and summary executions-as international crimes or crimes against hunıainty-1might be crimes for which amnesty should not be granted. ${ }^{201}$ Where such practices forn a pattern or system tolerated by officials of the state, he wrote, "the infringement of the "human condition' is such that the right of oblivion may become a right to

197. Geneva Convention IV, supra note 61, arts. 2, 146. Grave breaches, as defined in article 147, include willful killing, torture, and unlawful confinement. Id. art. 147.

198. Buergenthal, supra note 90, at 83-89; Schreuer, supra note 195, at 130.

199. See European Convention, supra note 130, art. 15(2); American Convention, supra note 20, art. 27(2); International Covenant, supra note 18, art. 4 (limits on derogation).

200. Study on Amnesty Laws and their Role in the Safeguard and Promotion of Human Rights, Prelim. Rept. by Mr. Louis Joinet, Special Rapporteur, U.N. Comm'n on Hum. Rts. (Provisional Agenda Item 9(a)), U.N. Doc. E/CN.4/Sub.2/1985/16 (1985) [heremafter Study on Amnesty Laws]. 201. Id. at 17 ๆ 62. 
impunity."202

A committee of international criminal law experts, convened to draft implementation measures for the United Nations Resolution and Declaration of Basic Principles of Justice for Victims of Criune and Abuse of Power, ${ }^{203}$ proposed a broader formulation. They posited that to "establislı and strengthen the means of detecting, prosecuting and sentencing those guilty of crimes," states should "ensure that public and military officials and agents receive no immunity from prosecution or disciplinary proceedings for victimization that was caused willfully ...."204 Therefore, botli pohcy and legal arguments support the conclusion that while a state may perimissibly pass amnesties for some offenses in response to a perceived eniergency, no amnesty may preclude investigation and prosecution of those responsible for offenses that violate nonderogable riglits-including freedon froin torture, forced disappearances, and extrajudicial executions.

In sum, this Part has establislied three compleinentary bases for finding a nonderogable treaty-based state obhgation to investigate grave liuman rights violations and to prosecute violators. Such an obligation may be based on international criminal law treaties, on the "ensure and respect" provisions of luman rights treaties, or as extensions of the right to a reniedy common to inany humian rights instrunients. The obligation is explicitly nonderogable when based upon criminal law treaties. In addition, it should be considered nonderogable if the underlying right is nonderogable. Therefore, amnesty laws purporting to immunize those responsible for summary execution, torture, or disappearances breach these treaties.

Not all countries are parties to one or more of the human rights instruments described above, ${ }_{2}^{205}$ and thus these treaty-based obligations would not apply to them. However, these countries would still be bound to investigate and prosecute hunian rights violators if the obligation had attained the status of a custoinary law norm. The next Part exainines that possibility.

202. Id. at 19 If 72.

203. G.A. Res. 40/34, 40 U.N. GAOR Supp. (No. 53) at 213, U.N. Doc. A/40/53 (1985) [hereinafter Declaration for Victims of Crimej (adopted by consensus), reprinted in INTERNATIONAL Protection OF VICTMMS (M. Bassiouni ed. 1988), at 201. For the implications of the Resolution as evidence of an enuerging customary law norm, see infra notes 266-75 and acconipanying text.

204. Implementation Principle R4(d).8., reprinted in InTERnational Protection of VICrrMs, supra note 203, at 31-32. The Implementation Primciple further states that obedience to superior orders-the justification for the Argentine amnesty-is not a defense in cases where tloose orders are manifestly illegal. Id. at 32.

205. The following table slows the total number of adherences to eacli trenty, the date of the adherence-if any-by the countries mentioned in this Comment, and the date of adlerence by selected other countries. Note that the entry for the American Convention lists separately those countries that have accepted the conpulsory jurisdiction of the Inter-American Court. 


\section{III}

\section{The Obligation to Investigate and Prosecute as CUSTOMARY LAW}

Together with treaties, customary international law is generally accepted as a binding source of law governing the international community. According to the Restatement of Foreign Relations Law, "customary international law results from a general and consistent practice of states followed by them from a sense of legal obligation."206

Three sources suggest that there is an emerging obligation under custornary international law to investigate grave human rights violations and take action against those responsible: (1) the treaty provisions and judicial decisions discussed in the previous Part, taken together; (2) state practice, including adherence to U.N. resolutions and state representations before international bodies; and (3) the law of state responsibility of injury to aliens, as updated in hight of human rights law. ${ }^{207}$ I will

\begin{tabular}{|c|c|c|c|c|c|c|c|c|}
\hline \multicolumn{9}{|c|}{ ADHERENCE TO HUMAN RIGHTS TREATIES } \\
\hline \multirow[t]{2}{*}{$\begin{array}{l}\text { Name of Treaty } \\
\text { (date entered into force) }\end{array}$} & \multirow[b]{2}{*}{$\begin{array}{c}\text { Total } \\
\text { Accessions }\end{array}$} & \multicolumn{4}{|c|}{$\begin{array}{l}\text { Country } \\
\text { (year = ratified or accepted) }\end{array}$} & \multirow[b]{2}{*}{ Hond. } & \multirow[b]{2}{*}{ Uru. } & \multirow[b]{2}{*}{ U.S } \\
\hline & & Argen. & Chile & El Sal. & Guat. & & & \\
\hline $\begin{array}{l}\text { Am. Deci. } \\
\text { (1948) }\end{array}$ & 21 & 48 & 48 & '48 & 38 & 48 & '48 & '48 \\
\hline $\begin{array}{l}\text { Geneva Convs. } \\
\text { (1950) }\end{array}$ & 167 & '49 & '49 & '49 & '49 & 49 & '49 & '49 \\
\hline $\begin{array}{l}\text { Genocide Conv. } \\
\text { (1951) }\end{array}$ & 99 & '56 & 53 & '50 & '50 & '52 & '67 & '88 \\
\hline $\begin{array}{l}\text { Conv. on War Crimes } \\
\text { (1970) }\end{array}$ & 30 & & & & & & & \\
\hline $\begin{array}{l}\text { Eur. Conv. H.R. } \\
\text { (1971) }\end{array}$ & 21 & & & & & & & \\
\hline $\begin{array}{l}\text { Int'l Covenant } \\
(1976)\end{array}$ & 87 & '86 & '72 & '79 & & & '70 & \\
\hline $\begin{array}{l}\text { Opt'1 Protocol } \\
\text { (1976) }\end{array}$ & 45 & '86 & & & & & '70 & \\
\hline $\begin{array}{l}\text { Ám. Conv. H.R. } \\
\text { (1978) }\end{array}$ & 20 & '84 & & '78 & '78 & '77 & '85 & \\
\hline $\begin{array}{l}\text { Comp. Juris. } \\
\text { Inter-Am. C.H.R. }\end{array}$ & 10 & '84 & & & '87 & '81 & '85 & \\
\hline $\begin{array}{l}\text { Conv. Torture } \\
\text { (1987) }\end{array}$ & 40 & '86 & '88 & & & & '86 & \\
\hline $\begin{array}{l}\text { Inter-Am. Conv. Torture } \\
\text { (1987) }\end{array}$ & 5 & & '88 & & '87 & & & \\
\hline
\end{tabular}

Sources: M.J. Bowman \& D.J. Harris, Multilateral Treaties, 6th Cum. Supp. (1989); Multilateral Treaties Deposited with the Secretary-General: STATUS as at 31 DeC. 1988, U.N. Doc. ST/LEG/SER.E/7, U.N. Sales No. E.89. v.6 (1989); HUMAN RIGHTS: THE INTER-AMERICAN SYSTEM (T. Buergenthal \& R. Norris eds. 1988).

206. RESTATEMENT, supra note $16, \S 102(2)$.

207. In proving that a rule has become law through custom, courts and other tribunals look at several types of evidence. Courts accord substantial weight to judgments and opinions of 
examine each of these sources in turn.

\section{A. Treaty Provisions as the Basis of the Customary Norm}

International instruments that allow any state to adhere and that are widely accepted may help to create customary international law, ${ }^{208}$ because they reflect the practice of states. Both the International Court of Justice and the Umited States Supreme Court have held that treaties can create binding obligations for nonparties if they reflect customary international law. ${ }^{209}$ As examined above, modern inultilateral treaties can embody an obligation to investigate and prosecute human rights violations. $^{210}$ Given their wide acceptance and universal character, then, they are proof that the obligation to investigate and prosecute can be considered binding on all states as custoinary imternational law.

The International Court of Justice (ICJ) in the North Sea Continental Shelf Cases $^{211}$ demonstrated the appropriate inquiry to determine whether a treaty provision is of a "norm-creatimg character" and thus part of customary law. The ICJ considered the nuniber of parties to the treaty, the structure of the treaty as a whole, and the subsequent state practice under the treaty. ${ }^{212}$ This inquiry is not limited to state parties to the treaty in question; thus, for example, the court in the Nottebohm Case ${ }^{213}$ drew on treaties to elucidate an international rule of nationality-despite the fact that the parties to the dispute were not parties to those treaties. ${ }^{214}$ Thus for the ICJ, treaty provisions of a "normcreating" character may become general rules of international law, espe-

international judicial and arbitral tribunals, writings of scholars, and resolutions of universal international organizations-if adopted by consensus or virtual unanimity or if explicitly declaratory of custonary law. Id. comment c. Confirmation of a right also found in many national laws may be persuasive in the case of luman rights norms. T. MERON, HUMAN RIGHTS AND HUMANITARIAN NoRMS AS CUSTOMARY LAW 94 (1989).

208. RESTATEMENT, supra note $16, \S 102(3)$. For a chart showing the number of parties adhering to major human rights and humanitarian law treaties, see supra note 205.

209. See infra notes 211-17.

210. See supra text accoinpanying notes 58-88, 131-58.

211. North Sea Continental Shelf Cases (W. Ger. v. Den.; W. Ger. v. Neth.), 1969 I.C.J. 3 (Feb. 20, 1969). Although technically ICJ decisions have no precedential value, in practice the court pays considerable attention to its own past decisions. Its opinions, and those of other international tribunals, carry great weight. RESTATEMENT, supra note $16, \S 103$ comnent b.

212. North Sea Continental Shelf Cases, 1969 I.C.J. at 41-43. For an authoritative treatment of the role of treaties in generating custom, see A. D'AMATO, THE CONCEPT OF CuSTOM IN INTERnATIONAL LAW 103-66 (1971). But see Weisburd, Customary International Law: The Problem of Treaties, 21 VAND. J. TRANSNAT'L L. 1 (1988) (concluding that treaties are simply one forn of state practice and that one cannot answer questions as to the content of custoinary international law simply by looking at the language of treaties).

213. Nottebohm (Liechtenstein v. Guat.), 1955 I.C.J. 4 (Apr. 6, 1955). For other cases in which the International Court of Justice relied on treaties to elucidate generally applicable rules of law, see A. D'AMATo, supra note 212 , at 116-20.

214. Nottebohni, 1955 I.C.J. at 21-23. 
cially if there was "very widespread and representative participation in the [agreeinent]."215

U.S. courts have also used treaties to deinonstrate the existence of a customary norm. For example, in the landmark Paquete Habana case, ${ }^{216}$ the Supreme Court gave heavy weight to numerous treaties that did not formally bind either of the two parties to the dispute in decidimg that international law prohibited the capture of nonbelligerent fishing vessels. $^{217}$ More recently, in Filartiga v. Pena-Irala, ${ }^{218}$ the Second Circuit reviewed several possible sources of customary international law prohibiting torture, but placed special emphasis on inultilateral instruments to support its holdmg that torture constitutes a tort "committed in violation of the law of nations."219

Some scholars who do not accept the general idea that treaties generally can bind nonparties through customary law are willing to accept that humanitarian treaties may do so. For example, Professor Baxter thought that "[i]n so far as they are directed to the protection of human rights, rather than to the interests of States, ... . [humanitarian treaties] have a wider claim to application than treaties concerned, for example, with the purely pohtical and economic interests of States."220 Humanitarian treaties have this special character because their very goals inay include the widest possible applicability and the generation or codification of custoin. ${ }^{221}$ In addition, human rights treaties build on one another and frequently have provisions in common or embody parallel concepts. The fact of similar provisions in numerous conventions provides even stronger evidence of a norm. ${ }^{222}$ Indeed, Professor Meron writes that "the repetition of certain norms in many human rights imstruments is itself an important articulation of state practice" and inay serve as a "preferred indicator" of customary status. ${ }^{223}$

The obhgation to investigate grave human rights violations and take action against those responsible is exphicit or imphicit in almost every major human rights-related instrument, through one or inore of the three

215. North Sea Continental Shelf Cases, 1969 I.C.J. at 41-42.

216. The Paquete Habana, 175 U.S. 677 (1900); see also A. D'AMATo, supra note 212, at 124-25 (explaining that the Court rehied heavily on treaties to which the flag country of the captured fishing vessels was not a party).

217. Paquete Habana, 175 U.S. at 686-700.

218. 630 F.2d 876 (2d Cir. 1980).

219. Id. at 883-84, 887 .

220. Baxter, Multilateral Treaties as Evidence of Customary International Law, 1965-66 BRIT. Y.B. INT'L L. 275, 286.

221. A. D'AMATo, supra note 212, at 151.

222. See, e.g., id. at 136 (State Department Legal Adviser, in a memorandum on river treaties, stated that "accepted legal doctrine" provides that custoin "may be inferred from similar provisions in a number of treaties").

223. T. MERON, supra note 207 , at $92-93$. 
types of provisions discussed in Part II. ${ }^{224}$ Through this repetition, the concepts of a right to a reinedy ${ }^{225}$ and of a state's obhigation to ensure rights are einerging as part of customary law in cases of fundamental, nonderogable rights like the prohibitions on torture, disappearances, and summary executions. Similarly, the principle of extradition or prosecution of offenders, a common feature of penal conventions since $1945,{ }^{226}$ is also ripening into a norin of customary law.

Moreover, most scholars consider at least one of the human rights mstruments, the Uiniversal Declaration, to have become customary law in its entirety. ${ }^{227}$ Because the Umiversal Declaration contains an explicit right to a remedy, ${ }^{228}$ the Declaration alone inight be sufficient to evidence a custoinary international obligation to investigate and prosecute.

\section{B. The Practice of States}

Although state-sponsored grave violations of human rights persist, and although states often fail to uphold their duty to investigate and prosecute allegations of violations, other aspects of state practice show tliat states do recognize these failures as breaches of international norms. The practice of states ${ }^{229}$ includes diploinatic acts and instructions, public measures and goverumental acts, and official statements of policy. ${ }^{230}$ States' atteinpts to initiate action against violators, verbal stateinents of government representatives, and resolutions and declarations are practices which inay evince a custonnary international law obligation to investigate and prosecute.

224. See supra text accompanying notes 58-158.

225. Professor Lillich disputes the notion that the right to a remedy is becoming customary international law, because the scope of the right differs as among the Universal Declaration and other conventions such as the International Covenant on Civil and Political Rights. Lillich, supra note 27, at 133-36. However, although the exact scope of this right is not settled (for cxample, cases where a remedy would be available under the International Covenant but not under a state's own constitution under the Universal Declaration), a state would always be obligated to investigate and prosecute forced disappearances and death squad murders, since they constitute violations of both international law and the fundamental domestic law of every state. Thus, with respect to these violations, imternational instruments demonstrate the type of consensus that Professor Lillich seeks.

226. See M. Bassiouni, International Criminal Law: A Draft International Criminal Code 45, 110 (1980).

227. See Lillich, Invoking International Human Rights Law in Domestic Courts, 54 U. CIN. L. REV. 367, 394-96 (1985) (citing the U.S. memorial in the Case Concerning United States Diplomatic and Consular Staff in Tehran (U.S. v. Iran), 1980 I.C.J. 3).

228. See supra notes 137-38 and accompanying text.

229. "Practice of States" need not be universal and may be developed over a short time period. RESTATEMENT, supra note $16, \S 102$ comment $b$. Inaction or acquiescence may also constitute state practice. Id. Similarly, a sense of legal obligation (opinio juris) may be inferred from acts or omissions; a practice initially followed as a matter of habit or comity may become law when states generally come to beheve that they have a legal obligation to follow the practice. Id. comment $\mathrm{c}$.

230. Id. comment b. 


\section{Prosecutions of Violators}

In a number of cases, successor governments investigated and prosecuted human rights violators after the fall of a military dictatorship despite the fact that the military retained some power. ${ }^{231}$ Although these prosecutions inay deinonstrate a sense of legal obligation to investigate and prosecute, they do not conclusively evidence a customary international law obligation because they may also be responses to donestic pohtical concerns.

The Greek experience is the most clearcut example of a state complying with the international obligations at issue throughout this Comment. ${ }^{232}$ After the fall of the colonels in August 1974, the civilian government moved quickly to tighten its control over the military apparatus, placing officers who had acquired reputations for brutal conduct on inactive status and half pay. ${ }^{233}$ In October, the government decreed that offenses committed by the dictatorship would not be subject to amnesty, that the persons charged with committing such crimes would be tried, and that former high officials would lose their pensions. ${ }^{234}$ In January 1975, the Greek Parhiament resolved that the crimes of the dictatorship from 1967 on would not be subject to any statute of limitations. ${ }^{235}$

In August 1975, after months of attempted coups and military uprisings, eighteen officers were convicted after month-long public trials,

231. States have also historically investigated and prosecuted human rights violators after a victorious revolution or uprising, as in Nicaragua, or after defeat in an international conflict, as in the Nuremberg and Tokyo trials and subsequent national trials of war criminals after World War II. See Zalaquett, Confronting Human Rights Violations Committed by Former Governments: Principles Applicable and Political Constraints, in STATE CRIMes: Punishment oR PaRdon 23, 45 \& n.40 (1989) [hereinafter STATE CRIMEs].

232. Events in Portugal and Uganda provide other examples of state investigations and prosecutions. See Maxwell, The Emengence of Portuguese Democracy, in From Dictatorship to DEMOCRACY: COPING WITH THE LEGACIES OF AUTHORITARIANISM AND TOTALITARIANISM 231, 241 (J. Herz ed. 1982) (noting that the Portuguese provisional government inoved rapidly to exile, imprison, or purge individuals associated with the old regime); Commission of Inquiry Investigates Causes of Abuses in Uganda, Huinan Rights Watch, Dec. 1989, at 7, 9. (Ugandan President Museveni created the Commission in 1986 to investigate past abuses and to propose safeguards against future ones. Highlights from the Coinmission's proceedings are broadcast on television every week. Several high-ranking security officers in former governments have been prosecuted, but lack of evidence has hampered convictions.)

As previously discussed, Argentina and Chile also have taken steps to investigate and prosecute offenders. See supra text accoinpanying notes 32-41, 52-55.

233. Psomiades, Greece: From the Colonels' Rule to Democracy, in From Dictatorship to DEMOCRACY: COPING WITH THE LEGACIES OF AUTHORITARIANISM AND TOTALITARIANISM 251, 258, 263-64 (J. Herz ed. 1982).

234. Id. at 259. Even this quick action was considered too slow by many private citizens, who initiated legal action against the junta leadership and officials, alleging treason and torture of political prisoners. Id. at 258.

235. Id. at 262-63. 
and eleven received life sentences for high treason. ${ }^{236}$ In September, the first trial on charges of torture resulted in long prison sentences for the commanders of the junta's most notorious detention center, while lowerranking officers and enlisted men either were given highter sentences or were acquitted. ${ }^{237}$ Other torture trials followed; several hundred were held over the next year or so. ${ }^{238}$

It is hard to determine, however, the extent to which the purges and prosecutions were based on domestic pohtical concerns rather than a sense of legal obligation. Furthermore, there are examples of mcoming democratic governments that chose not to take action against former human rights violators. ${ }^{239}$ Thus, the decision whether to prosecute does not necessarily demonstrate the commitment to redressimg rights violations, nor by imphication the existence of the norm.

\section{Provisions of Domestic Law}

The domestic legislation of states, if consistent throughout major legal systems, is another crucial indicator of state practice, especially in the human rights context. ${ }^{240}$ Torture, abduction and suminary execution (and probably, by extension, disappearances), are prohibited and subject to penal sanction throughout the world. ${ }^{241}$ Many Latim American countries impose special penalties when the accused is a public official, or where public officials fail through lack of due diligence to prevent the violation. $^{242}$ Moreover, over the last fifty years, some major legal systems, especially in Western countries, have begun to provide some form of civil redress against unlawful official acts. ${ }^{243}$

236. Id. at 264 .

237. Id. at $264-65$.

238. Id. at 265; see also AMNESTY INTERnAtional, TORTURe in Greece: The First TORTURERs' TrIal 1975, at 63 (1977) (reporting government figures that show froin 100 to 400 trials, and asserting that most defendants were given light or suspended sentences).

239. In Spain, for instance, the nature of the civil war, the long transition period, and the negotiated nature of the transition to civilian rule precluded prosecutions of Francoists. See Maxwell, supra note 232 , at 241 . In other countries, the failure to prosecute may reflect the government's inability or unwillingness to take human rights and security policy away from the military, as in El Salvador or Guatemala. See AW, MUTUAL SUPPORT, supra note 178; AW \& ACLU, El SALVADOR, supra note 8, at 5, 62.

240. See T. MERON, supra note 207, at $93-94$ (confirming that the right is incorporated in national laws and thus exists in national practice; and noting that this is a preferred indicator of customary human rights).

241. Summary execution would usually be prohibited as inurder, and disappearance as abduction or kidnapping.

242. See, e.g., Cód. PEN. art. 144(3) (Argen.) (1985) (prison term for torture); art. 144(4) (prison term for complicity in permitting torture); art. 144(5) (prison term for negligence in permitting torture); CóD. PEN. art. 340 (Peru) (1985) (prison for public officials who illegally arrest, mistreat or are complicit in mistreatınent of persons).

243. See L. Hurwitz, The State as Defendant 22-23 (1981). For example, in U.S. law, 42 U.S.C. $\S 1983$ allows individuals to bring a civil suit against officials acting under color of state law; 
Nonetheless, one could conclude that there is little consistent state practice supporting an obligation to investigate and prosecute if one considered the entire corpus of internal governmental acts. The amnesties described in Part II, for example, ${ }^{244}$ could be interpreted as examples of contrary state practice. However, amnesties granted for political offenses have often in the past excluded persons guilty of committing crimes against humanity, ${ }^{245}$ such as former Nazis in the German Deinocratic Republic and Roinama, and inore recently, in Hungary. ${ }^{246}$ A 1982 Colounbian amnesty law excluded those guilty of torture, forced disappearances, or executions. ${ }^{247}$ In Portugal, a constitutional provision excludes froin any amnesty high-level, security-force officials accused of ordering torture. ${ }^{248}$ Indeed, the original 1984 Argentine law authorizing military prosecutions of those accused of human rights violations excluded froin its due obedience clause those accused of "atrocious and aberrant acts." ${ }^{249}$ Thus, national laws provide support for the existence of a norm which, though it does not require investigation and prosecution in every case, does do so for the serious human rights violations at issue. ${ }^{250}$

It should be apparent that state practice is a particularly difficult indicator of custom in the human rights area. ${ }^{251}$ Therefore, courts and commentators have turned to additional indicators of practice to determine which human rights norms have attained the status of custom. Although evidence of inconsistent state practice would normally militate against the existence of a custonary norm, the International Court of Justice has found that inconsistency carries less weight in the field of

the French Conseil d'Etat and the Scandinavian Ombudsman also provide citizens with civil redress against abuse by officials. L. HuRWITZ, supra, at 194.

244. See supra text accompanying notes 187-88, 193; Study on Amnesty Laws, supra note 200.

245. For a definition of crimes against humanity, see supra note 58.

246. Study on Amnesty Laws, supra note 200, at 15.

247. Id. at 17 n.20.

248. Id. at 19 (citing Const. of the Portuguese Republic art. 309).

249. AW, ARGENTINA, supra note 30, at 19.

250. Because the obligation to investigate and prosecute is common to many legal systems, it nay be considered a general principle of law. "The general principles of law recognized by civilized nations" are a source of international law. Statute of the I.C.J., art. 38(1)(c); see also M. JANIS, supra note 185 , at $47-49$.

251. For exaniple, courts and commentators agree that torture is proscribed by customary international law, see, e.g., Filartiga v. Pena-Irala, 630 F.2d 876, 881-83 (2d Cir. 1980); Forti v. Suarez-Mason, 694 F. Supp. 707 (N.D. Cal. 1988) (finding a universal and obligatory proscription against "causing disappearance"); Forti v. Suarez-Mason, 672 F. Supp. 1531 (N.D. Cal. 1987) (following Filartiga and finding a universal and obligatory proscription against official torture, and that there are similar proscriptions against prolonged detention and summary execution); Rodley, supra note 2, at 169-70, but nonetheless inany states continue to employ it. See AMNESTY INTERNATIONAL, TORTURE IN THE EIGHTIES 2 (1984) (Inore than one-third of the worlds' governments used or tolerated torture or ill-treatment of prisoners in the 1980s). 
human or humanitarian rights. ${ }^{252}$ Instead, the court has focused on verbal statements of governmental representatives to imternational organizations, the content of resolutions and declarations adopted by such organizations, and the consent of states to such instruments. ${ }^{253}$ These indicators yield a much clearer pattern of both state practice and opinio juris ${ }^{254}$ suppporting a customary obligation to investigate and prosecute.

\section{Verbal Statements of Governmental Representatives}

States are quite unwilling to say outright that they have no obligation to imvestigate or prosecute human rights violators, just as they are unwilling to announce their rejection of other fundaniental human rights. Even where governments have passed amnesty laws, they have not demied the existence of an obligation to investigate and prosecute, but rather have justified their acts as required by exigent circumstances that override the obligation..$^{255}$

In their representations to international bodies, state representatives have stressed their comphance with the norm. So, for exaniple, although the Uruguayan civilian government ultimately enacted a virtual amnesty law, it assured the U.N. Human Rights Commission upon first taking office that it would investigate the human rights violations committed under the previous dictatorship and bring the perpetrators of these abuses to justice. ${ }^{256}$ One year later, Uruguay's permanent delegation to the U.N. made a similar pledge to the Human Rights Coinmittee that oversees comphance with the International Covenant on Civil and Political Rights. ${ }^{257}$

In 1984, the Chilean representative, responding to questions by members of the Human Rights Committee regarding Chile's compliance with its international obligations, assured the Committee that Chilean authorities were investigating disappearances, and that persons responsible who had been identified had been brought to justice. ${ }^{258}$ El Salvador's

252. T. MERON, supra note 207, at 113 (citing the Intemational Court of Justice's analysis of humanitarian law in the Nicaragua case, supra note 76, at 98-108); see also Western Sahara, 1975 I.C.J. 12, 30-37 (Advisory Opinion of Oct. 16, 1975) (using U.N. General Assembly resolutions as evidence of customary law).

253. T. MERoN, supra note 207 , at 42 . Baxter also approved of this method, writing that "[t]he firm statement by the State of what it considers to be the mle is far better evidence of its position than what can be pieced together from the actions of that country at different times and in a variety of contexts." Baxter, supra note 220 , at 300.

254. See supra note 229.

255. See, e.g., Esto no me gusta, in M. SANCINETTI, DeREChos Humanos EN la ARGENTINA POST-Dictatorial 277-78 (1988) (address to the nation by then-President Raul Alfonsin, May 13, 1987).

256. AW, Challenging IMPUNITY, supra note 44 , at 12 .

257. Id.

258. Consideration of Reports Submitted by States Parties Under Article 40 of the Covenant (Chile), 22 U.N. Human Rights Committee (529th mtg.) at 4-5, U.N. Doc. CCPR/C/SR.529 (1984) 
representative told the Committee in 1987 that then-President Duarte's government had abohished a police section suspected of liuman rights violations and had brought nearly 1,000 inembers of the armed forces and security forces to trial for human rights violations. ${ }^{259}$ The questions of the Committee about compliance and the assurances of state representatives that they were indeed complying with their responsibilities indicate that states believed they were bound to do so. ${ }^{260}$

In their diplomatic and pohtical interchanges with each other, states also slow recognition of an international obligation to investigate and prosecute. For example, the U.S. government has conditioned foreign aid to El Salvador on satisfactory investigation and prosecution of those responsible for death squad killings of non-U.S. nationals. ${ }^{261}$ The United States recalled its ambassador to Guateinala to protest the lack of prosecutions in human riglits cases. ${ }^{262}$ In response to U.S. pressure-includ-

[hereinafter Chile Report] (remarks of Mr. Calderon). Members of the Committee also implied that Chile had an obligation to investigate and prosecute luman rights violators. For example, referring to disappearances, Mr. Ermacora asked "what had the authorities done to establish the facts. The same question applied to the mass graves and secret burial places which had been found." Id. at 2 . Mr. Graefrath "wished to have details of the number of persons prosecuted for performing secret executions, of public bodies other than the courts which had been responsible for making investigations and of any compensation to which the families of the victims had been entitled." Id. at 3. Mr. Errera asked about the number and result of complaints filed alleging torture, the police or inilitary rank of the culprits, whether the prosecutions or sentences had been affected by a claim of superior orders or by an amnesty, and whether disciplinary measures had been taken against certain members of the police or army. Id. at 6. Finally, Mr. Prado Vallejo stated that it was Chile's duty to put an end to the impunity with which acts of torture pere committed. Id. at 7.

259. Consideration of Reports (El Salvador), 29 Human Rights Committee (719th mtg.) at 4, U.N. Doc. CCPR/C/SR.719 (July 7, 1987) (remarks of Mr. Trejo Padilla). Representations by states parties regarding their compliance with an obligation to mvestigate and prosecute are by no means linited to Latin America. See, e.g., Consideration of Reports (United Kingdom), 24 Human Rights Committee (596th mtg.) at 3, U.N. Doc. CCPR/C/SR.596 (1985); Initial Reports of States Parties due in 1978 (Zaire), Human Rights Committee at 17, U.N. Doc. CCPR/C/4/Add. 10 (1987) (requested 24th Sess., 1985); Consideration of Reports (Rwanda), 31 Human Rights Committee (783rd mtg.) at 7, U.N. Doc. CCPR/C/SR.783 (1987).

260. Of course, it could be argued that this obligation only refers to duties under the Covenant and not under customary law. However, Committec members, by referring to the Universal Declaration of Human Rights, the draft Torture Convention, the International Covenant, and other instruments, seemed to frame the issue in broader terms. See Chile Report, supra note 258, at 5-6.

261. U.S. Warns Salvador on Rights Cases, N.Y. Times, Jan. 7, 1989, § 1, at 3, col. 4; see also Quayle Pressed Salvador for Inquiry on Massacre, N.Y. Times, Feb. 15, 1989, at A6, col. 4; Foreign Operations, Export Financing, and Related Programs Appropriations Act of 1990, Pub. L. No. 101167 , § 599G(a)(3), 103 Stat. 1195 (1989). Section 559G(c) of the Act withholds $\$ 5$ million in military assistance until the President certifies a report on the efforts of the government of El Salvador to bring to justice the perpetrators of a massacre of ten peasants. Many legislators have also expressed concern over the failure to successfully prosecute the inurderers of Salvadoran Archbishop Oscar Romero, and have advocated tying continued U.S. aid to investigation and prosecution of the death squad killing of six Jesuit priests, their housekeeper, and her daughter. See, e.g., Chicago Tribuue, May 2, 1990, at 1 (Bush administration proposes tying military aid to El Salvador to progress of investigations, to avert showdown with Congress); 136 CoNG. REC. H265802 (May 22, 1990) (statements of Rep. Studds, Rep. Green).

262. Guatemalan Says U.S. is Unfair on Rights, N.Y. Tines, Mar. 7, 1990, at 3, col. 1. 
ing a ban on U.S. aid-the Chilean government assured the State Department that it was "making all efforts to bring to justice the murderers of [ex-Chilean foreign minister Orlando] Leteher."263 Polish leaders have called on the Soviet Umion to follow up on its admission that the Soviets were responsible for the Katyn forest massacre in 1940 by prosecuting those guilty of the crime. ${ }^{264}$ The admission of Soviet guilt was terined important for future Polish-Soviet relations. ${ }^{265}$

\section{Resolutions and Declarations of International Organizations}

In 1985, the Umited Nations General Asseinbly unanimously passed a resolution adopting the Declaration of Basic Principles of Justice for Victims of Crime and Abuse of Power. ${ }^{266}$ The resolution calls on member states to "enact and enforce legislation proscribing acts that violate internationally recognized norms relating to human riglits"267 and to "establish and strengthen the means of detecting, prosecuting and sentencing those guilty of crimes."268 Furtherinore, the General Asseinbly recommended that all appropriate means should be taken to develop "recourse for victims where national channels may be insufficient."269

The Declaration itself does not distinguish between victims of private (common) crime and victims of grave human rights abuses, except to declare that "[w] here public officials or other agents acting in an offcial or quasi-official capacity have violated national criminal laws, the victims should receive restitution from the State ...."270 However, the implementation measures developed by a group of international criminal law experts at the request of the General Assembly ${ }^{271}$ shed furtlier light on the scope of the Declaration. In order to "establish and strengthen the means of detecting, prosecuting and sentencing those guilty of crimes," the Implementation Principles call on states to

conduct impartial investigations as soon as possible into all deaths and serious physical and mental injuries apparently caused by law enforcement, military, administrative, medical and other professional personnel and into all deaths and serious physical and mental injuries apparently in

263. The Chilean government also agreed to pay compensation to the Letelier family. Congress had conditioned further aid and arms sales on Chile's taking "appropriate steps" to bring to justice those indicted in the United States for the Letelier nurder. Chile Agrees to Pay Compensation In Case of Diplomat Slain in U.S., N.Y. Times, May 13, 1990, at 1, col. 4.

264. Poles Urge Charges in Katyn Massacre, N.Y. Times, Apr. 14, 1990, at 5, col. 3.

265. Id.

266. Declaration for Victims of Crime, supra note 203.

267. Id. ी 4(c).

268. Id. $\cap 4$ (d).

269. Id. If $5(\mathrm{~d})$.

270. Id. at annex $₫ 11$.

271. Bassiouni, Introduction to the United Nations Resolution and Declaration of Basic Principles of Justice for Victims of Crime and Abuse of Power in INTERNATIONAL Protection of VICTIMS, supra note 203, at 19. 
custody or in public institutions ...; [and to] prosecute persons who victimize others by committing serions crimes or extradite such persons to another state lraving jurisdiction. ${ }^{272}$

Further, the Implementation Principles call on states to provide compensation to victims of crimes violatimg international human rights instruments and of crimes against humainty, ${ }^{273}$ and to "ensure that legal or disciplinary action is taken against persons who fail to comply with legislation or regulations governing arrest, searches, interrogation, and detention."274 These principles for implementing a unanimous General Assembly resolution, drafted under the auspices of the U.N. Economic and Social Council, ${ }^{275}$ provide strong evidence that states, through their public statements, accept the norins at issue.

Further evidence comes froin a draft resolution of the U.N. Committee on Crime Prevention and Control entitled "Effective prevention and investigation of extra-legal, arbitrary and summary executions."276 The draft resolution sets out international standards for investigating and prosecuting these grave violations of human rights. The standards for imvestigation require, inter alia, publication of the findings. Those governing prosecution prohibit invoking superior orders to justify participation in extralegal, arbitrary, or summary executions; disallow any blanket immumity from proseeution for any person allegedly involved in such acts; and require that fair and adequate compensation be paid to the fainilies and dependents of victims. ${ }^{277}$ This effort is yet another reflection of increasimg concern on the part of states, at least in their statements in international bodies, to make investigation and prosecution of grave human rights violations clearly legally obhigatory.

The evidence of an emerging norm provided by treaty provisions, state practice, verbal statements of governinental representatives, and resolutions and declarations is undoubtedly mixed. But taken together, these sources support a finding that an obligation to investigate certain gross and systematic human rights violations and take judicial or admin-

272. International Protection of Victims, supra note 203, at 31-32 (Implementation Principles R4(d).5. and R4(d).6.). Recall also that R4(d).8. prohibits immunity from prosecution for public officials and agents. See supra note 204 and accompanying text.

273. International Protection of Victims, supra note 203, at 78 (Implementation Principle 18.2.).

274. Id. at 79 (Implementation Principle 19.4.).

275. The Implementation Principles grew out of General Assembly Resolution 40/34 and a subsequent meeting of experts. See supra text accounpanying note 271. The text was submitted to the United Nations in April 1988 for approval. Preface to INTERnational Protection of VICTIMS, supra note 203, at 11-12.

276. Draft Resolution X, 10 U.N. Committee on Crine Prevention and Control (17th. mtg.) at 30, U.N. Doc. E/AC.57/1988/17 (1988), sununarized in Summary or Arbitrary Executions, Report by the Special Rapporteur, Pursuant to Economic and Social Council Resolution 1988/38, 45 U.N. Comm'n on Hum. Rts. (25th mtg.) at 58, U.N. Doc. E/CN.4/1989/25 (1989).

277. Id. The resolution was scheduled to be voted on at the next ECOSOC session. Id. 
istrative action agamst those responsible is now part of customary law. In addition, policy reasons support reading the evidence in the broadest possible hight. A determination of whether a customary rule has developed is influenced by whether the rule will contribute to international order. ${ }^{278}$ Imposing an affirmative obligation on states to investigate grave human rights violations and take action against those responsible would contribute to world public order and has a clear moral basis. States should therefore be held to their word. ${ }^{279}$

Not only does state practice evidence a customary international law norm, but the decisions of international tribunals and scholarly works addressing the doctrime of state responsibility have found an obligation to investigate and prosecute. ${ }^{280}$ Once limited to states' responsibility for physical or economic harm to aliens, the law now may extend to a state's treatınent of its own citizens.

\section{Prior Customary Law: State Responsibility for Injuries to Aliens and the Obligation to Investigate and Prosecute}

The law of state responsibility concerns the conditions under which a state incurs international liability for its actions. ${ }^{281}$ From its origins in determining the rules under which states redressed injuries to tlieir nationals abroad, the law lias now been partially codified by the U.N. International Law Commission and formulated in terms that extend well beyond treatınent of aliens. ${ }^{282}$ In its modern version, the doctrine converges with human riglits law.

Even prior to tlie development of modern liuman rights law, principles of classical international law supported the existence of a state's obligation to investigate and prosecute. The law of diplonatic protection lolds a state responsible for injuries to aliens committed witlin its territory. ${ }^{283}$ Altliougl the fundamental responsibility of the state is to provide compensation, there is also an obligation to investigate the facts surrounding the incident and pumisli tliose responsible. ${ }^{284}$ The failure to

278. RESTATEMENT, supra note $16, \S 103$ comment a.

279. See T. MERON, supra note 207, at 43-45.

280. Decisions of international tribunals and scholarly works are accorded substantial weight in determining whether a rule has become international law. RESTATEMENT, supra note $16, \S 103(2)$.

281. The doctrine has been termed "the international law of tort applicable to States." Yates, State Responsibility for Nonwealth Injuries to Aliens in the Postwar Era, in INTERNATIONAL LAW OF STATE RESPONSIBILITY FOR INJURIES TO AliENS 213 (R. Lillich ed. 1983) [hereinafter INT'L RESPONSIBILITY].

282. See [1976] 2 Y.B. INT'L L. CoMm'N, pt. 2, 69-70, U.N. Doc. A/CN.4/SEP.A/1976/ Add.1 (Part 2).

283. Lillich, The Current Status of the Law of State Responsibility for Injuries to Aliens, in INT'L RESPONSIBILITY, supra note 281, at 1-3.

284. M. Whiteman, I DAmages In INTERnational LAw 38 (1937) (a state's failure to 
do so is itself a breacll of the state's international obligations. ${ }^{285}$

International responsibility arising from a failure to investigate and prosecute was a inajor focus of the decisions of late nineteentli and early twentieth century mixed commissions formed to arbitrate claims based on injuries to aliens. An example is the United States-Mexican General Claims Commission. ${ }^{286}$ The Commission was formed to mediate claims of da1nages to U.S. citizens arising from the Mexican Revolution. It was to base its decisions on the then-estabhished rules of international law. ${ }^{287}$

Several Commission decisions held that, under international law, the state is responsible for failure to attempt diligently to appreliend the assailant of an alien. In the Neer Case, ${ }^{288}$ the Commission held that the sufficiency of governmental action taken to investigate and apprehend an assailant should be put to the test of international standards. The Commission estabhished that: (1) international standards can obhgate national authorities to take affirmative actions to investigate and apprehend; (2) failure to do so is a breach of a legal duty, giving rise to an international delinquency; and (3) even if the laws on the books are sound, the failure to provide effective execution constitutes a breach. ${ }^{289}$

The Janes Case ${ }^{290}$ provides the clearest example of hability based on a failure to prosecute an assailant. Janes, a U.S. citizen, was killed by a Mexican who was apparently allowed to escape by the Mexican authorities. The Commission held that the Mexican government was "hable for not having measured up to its duty of diligently prosecuting and properly

investigate a crime or to punish a person who has injured an alien is commonly termed a denial of justice on the part of the state).

285. Id.

286. See A. Feller, The Mexican Claims Commissions 1923-1934, §§ 143-145, at 149-54 (1935); see also M. WhitemaN, supra note 284, at 40-60.

287. The international law rules governing state responsibility during this time reflected the balance of power favoring strong nations like England and the United States over weak ones like Mexico or Venezuela; thus the rules favored aliens since they were usually from the dommant states. Reacting to this imbalance, Latin American nations developed the "national treatnent" standard, arguing that international law only required that aliens and nationals be treated alike. Both that standard and the "international mimimum" standard of the claims commissions are now subsunied under the International Law Commission's draft. See infra note 307 and acconpanying text.

288. Neer Case (U.S. v. Mex.), 1927 United States and Mexico General Claims Commission 71, 4 R. Int'l Arb. Awards 60 (1926).

289. The Commission stated that

the treatment of an alien, in order to constitute an international delinquency, should amount to an outrage, to bad faith, to wilful neglect of duty, or to an insufficiency of governmental action so far short of international standards that every reasonable and inpartial man would readily recognize its insufficiency. Whether the insufficiency proceeds from deficieut execution of an intelligent law or from the fact that the laws of the country do not einpower the authorities to measure up to international standards is imniaterial.

Id. at 73, $4 \mathrm{R}$. Int'1 Arb. at 61-62.

290. Janes Case (U.S. v. Mex.), 1927 United States and Mexico General Claims Commission 108, 114-19, 4 R. Int'1 Arb. Awards 82 (1926) [hereinafter Janes Case]. 
punishing the offender."291

The Commission examined two possible theories on which to base state responsibility. The first, cited in earher arbitral decisions, posited that the failure to punish wrongdoers should be deemed approval of the criminal conduct, and should give rise to a presumption of governinent comphicity in the murder itself. This presumption was especially apphicable where the government had allowed the guilty parties to escape or had granted pardon or amnesty. ${ }^{292}$

The Commission rejected this view, holding instead that the failure to prosecute and punish was a separate offense of the state. ${ }^{293}$ Danages should therefore include not only compensatory damages for Janes' death, but separate damages to the family for the indignity of the lack of punishinent. ${ }^{294}$ In addition, "a reasonable and substantial redress should be made for the mistrust and lack of safety, resnlting from the Government's attitude."295

Nor can granting an amnesty to those involved in civil strife negate the state's responsibility. If the amnesty renders an assailant immune from prosecution, it has the same effect as a failure to punish a crime, rendering the state indirectly responsible. Thus, in the West Case, ${ }^{296}$ the Commissioners awarded \$10,000 to the survivors of an American oil well driller killed by rebel forces who were subsequently granted ainnesty. The Commission refused to look into whether the amnesty was properly apphied under Mexican law, ${ }^{297}$ or to recognize that reasons of national pohcy might dictate granting amnesty to rebel troops as a way of ending years of civil strife. ${ }^{298}$ The principle that a domestic amnesty does not affect international obhigations of the state, then, has long been estabhished in international law. ${ }^{299}$

These cases, and many others of international tribunals and arbitrators, ${ }^{300}$ found that states were internationally responsible when their officials failed to investigate adequately or prosecute those responsible for crimes. Unlike the obligation to imvestigate and prosecute proposed by this Comment, however, the state's obligation in these cases only arose

291. Id. at $115,4 \mathrm{R}$. Int'l Arb. at 87 .

292. Id. at $114,4 \mathrm{R}$. Int'l Arb. at 86-87.

293. Id. at 114-15, $4 \mathrm{R}$. Int'l Arb. at 87.

294. Id. at 118, $4 \mathrm{R}$. Int'l Arb. at 89.

295. Id. at 119, 4 R. Int'l Arb. at 89.

296. West Case (U.S. v. Mex.), 1927 United States and Mexico General Claims Commission

404, 4 R. Int'l Arb. Awards 270 (1927).

297. Id. at 406, 4 R. Int'l Arb. at 272.

298. However, the effect of an amnesty was less clear to the Commissioners in the case of General Villa, where the need to end civil strife apparently outweighed other considerations. See A. FELLER, supra note 286, § 145, at 151 n.63.

299. See supro notes 184-85 and accompanying text.

300. See, e.g., cases cited in M. WHITEMAN, supra note 284 , at 38-69. 
when the victim was a national of another state. The holdings were based at least partly on the idea that an injury to a national is an injury to the state to which the national belongs. Because the state's traditional sovereignty over "the persons and property of its own nationals" did not extend to foreigners, international law could inquire into a state's internal processes. ${ }^{301}$

These cases arose at a time when international law did not concern itself with the individual's rights vis-à-vis her own state, but only with relations between states. But since World War II the subjects of international law have changed dramatically; individuals generally, and especially the protection of individual rights against violation by any state, have become important concerns. ${ }^{302}$ Furthermore, the breach of certain international obhgations is now considered of concern to all nations. ${ }^{303}$ The mcorporation of these new developinents in international law into the law of state responsibility has been a major preoccupation of scholars since World War II.

Phillip Jessup explored some of the changes in the law of state responsibility

which would be necessary or desirable if individuals were directly invested with rights and duties under international law and if there were a recognition of a legal doctrine of community interest in breaches of the law. ... .

The topic formerly known in international law as "the responsibility of states for injuries to aliens" might be transformed into "the responsibility of states for injuries to individuals." 304

While there still imight be a need for special protections for aliens and procedural differences in how a claim would be brought, a state wonld owe an international duty with respect to the treatment of its own nationals.

These two concerns-individual rights and community interest in

301. See Janes Case, (U.S. v. Mex.), 1927 United States and Mexico General Claims Commission 108, 123-24, 4 R. Int'1 Arb. Awards 82, 92-93 (1926) (separate statement of Commissioner Nielsen).

302. For a discussion of the rise of the individual as a subject of international law, see Belsky, Merva \& Roht-Arriaza, Implied Waiver Under the FSIA, 77 CALIF. L. REv. 365, 392-93 (1989).

303. See supra note 131 (soine obligations are erga omnes). The International Law Commission's draft articles on state responsibility distinguish between international crimes and international delicts. International crimes involve violations of an obligation that is "so essential for the protection of fundamental interests of the international community that its breach is recognized as a crime by the international community as a whole." Int'l Law Comm'n, Draft Articles on State Responsibility, [1976] 2 Y.B. INT'L L. CoMM'N 95, art. 19, U.N. Doc. A/CN.4/SER.A/1976/Add.1 (Part 2). If a crime is an offense against the community of states as a whole, the obligation to remedy also rnns to all states. RESTATEMENT, supra note $16, \S 901$ reporter's note 1 .

304. See generally Jessup, Responsibility of States for Injuries to Individuals, 46 CoLUM. L. REV. 903, 904-10 (1946) (einphasis in original). Jessup envisioned an international bill of rights as the inechanism for making effective the individnal's rights against his own state. Id. at 911 . 
breaches-were of paramount concern to the members of the International Law Commission (ILC) assigned by the Umited Nations General Assembly to codify the principles of international law governing state responsibility. F. Garcia Amador, the first Reporter for the ILC's project on state responsibility, wrote that earlier standards used to assess conduct vis-à-vis aliens were now obsolete. He argued that the new standard would be "umversal respect for, and observance of, human rights and fundamental freedoms."305 The standards for judging international responsibility - mcluding those relating to failure to investigate or prosecute crimes-would be applicable whether the victim is a citizen of the same or a different state. ${ }^{306}$

The parallel between the older concept of state responsibility for injury to aliens and its formulation in more recently developed human rights law is striking. Both are concerned with protecting individuals against improper state action. Both estabhsh ininimum standards for state conduct: the older concept of "international minimuin standards" set out the permissible limits of a state's conduct, while the theory of "national treatment" postulated that aliens and nationals should be treated alike. ${ }^{307}$ Human rights law imported both ideas, and is beginning to merge them into one umiversal standard for state responsibility. The convergence of these two traditions extends the state's obligation to investigate and prosecute, already well developed with respect to aliens, to cover its own nationals.

The rules of state responsibility support the other sources of customary law discussed above ${ }^{308}$ in proving the emergence of a human rights norm imposing an affirmative obligation on states to investigate and prosecute grave human rights violations. But just as certain treaty obligations may be derogable, state responsibility arising from customary law norms may be subject to exceptions. The exceptions may provide that acts not conforming to a state's international obhgations are nonetheless

305. State Responsibility, [1956] 2 Y.B. INT'L L. CoMM'N 173, 203, U.N. Doc. A/CN.4/ SER.A/1956/Add.1 (F. Garcia Amador, reporter) (quoting the U.N. Charter and other general, regional, and bilateral instruments).

306. Unfortunately, Garcia Amador's ideas were not adopted at later meetings of the International Law Commission on the subject. However, they are now receiving renewed interest from scholars. See Lillich, The Current Status of the Law of state Responsibility for Injuries to Aliens, in INT'L RESPONSIBILITY, supra note 281, at 26. The current ILC Draft Articles on State Responsibility do not differentiate between aliens and citizens. Moreover, they clearly state that state responsibility is incurred by a violation of imternational obligations, which include those based on treaty and customary law. T. MERON, supra note 207, at 155 n.55 (citing Int'l Law Comm'n, Draft Articles on State Responsibility, [1975] 2 Y.B. INT'L L. CoMM'N 60, art. 3, U.N. Doc. A/ CN.4/SER.A/1975/Add.1.).

307. See Yates, State Responsibility for Nonwealth Injuries to Aliens in the Postwar Era, in INT'L RESPONSIBILITY, supra note 281, at 214-15.

308. See supra text accompanying notes 231-77. 
not wrongful. ${ }^{309}$

\section{Necessity as an Exception to the State Obligation}

Parallel to the concept of "public emergency" as a justification for derogations of treaty rights ${ }^{310}$ is the idea of necessity in the customary law of state responsibility. The International Law Commission defines necessity as existing when a state is threatened by a grave and imminent peril and its sole means of safeguarding an essential interest is to adopt conduct not in conformity with what is required of it by an international obligation. $^{311}$

Because necessity is only a defense to a customary obligation, a state cannot invoke necessity to overcome an obligation created by a conventional instrument. ${ }^{312}$ In addition, the ILC draft does not allow a state to invoke necessity if the state itself contributed to the occurrence of the condition of necessity. ${ }^{313}$

Thus, for a state to invoke necessity as a way of avoiding its obligation under customary law (for example to justify an amnesty for human rights offenders), it must show that there were no alternative means of confronting the danger, that it did not contribute to creating the danger, and that such an amnesty is not prohibited by treaty. In general, this is a heavy burden of proof, justified by the "important community values implicated in protecting human rights." 314 It seems impossible for a state like Argentina or Uruguay to avoid its responsibilities, $\dot{n} 1$ that it was precisely members of the state (military or security forces) who caused the danger in the first place. ${ }^{315}$ Therefore, necessity, like derogability in the treaty context, could not easily be invoked to justify an amnesty or to avoid an affirmative obligation like the one proposed in this Comment.

IV

Policy IMPLICATIONS OF AN INTERNATIONAL OBLIGATION to Investigate and Prosecute

Parts I througlı III of this Comment liave established the existence

309. T. MERON, supra note 207, at 215.

310. See supra notes 189-204 and accompanying text.

311. In'1 Law Comm'n, Draft Articles on State Responsibility, [1980] 2 Y.B. INT'L L. COMM'N 26, 33, U.N. Doc. A/CN.4/SER.A/1980/Add.1 (art. 33(1)(a) of the Draft Articles on Responsibility of States for Internationally Wrongful Acts).

312. Id. art. 33(2)(b). See also discussion of nonderogable treaty provisions, supra notes 199-202 and accompanying text.

313. Draft Articles on State Responsibility, supra note 311, art. 33(2)(c).

314. T. MERON, supra note 207 , at 220.

315. As discussed above, international obhigations mure to the state, not the government, so that a suecessor government is generally responsible for its predecessor's obligations. See supra note 185 and accompanying text. 
in international law of an obligation for states to investigate and prosecute the most grave violations of human rights. Part IV will examine the policy implications of enforcing this norm througl1 eitler international mechanisms like the U.N. Human Rights Committee or through regional courts like the Inter-American Court. It will also examine tlie use of this norm as a basis for domestic and international public pressure on recalcitrant governments. These issues have no easy resolution; consequently this Comment only sets out the relevant questions and considerations.

The policy implications vary with the type of government currently in power. In countries where large-scale human rights violations continue (whether under military or nommal civilian rule), the main effect of enforcing a norm of obligatory investigation and prosecution will be to shift the burden of proof for certain types of abuses. In these cases, a relevant consideration will be the effect of the norm on the reluctance of those in power, if they fear future prosecution, to turn control over to a successor.

In countries where a return to civilian rule lias been accompanied by an end to most grave human rights abuses, the imphications are very different. There the question is one of whether, and low, to prosecute abuses of former governments. Concerns for the stability of the new government, the perceived need for national reconciliation, and larger questions of the ethics of using prosecution for purposes of deterrence or retribution are all relevant queries. In every case, further, a balance inust be struck between the state's sovereignty interest in applying doinestic legal norms and the international community's interest in protection of international human rights norms.

\section{A. Implications for Governments Where Abuses Continue: Shifting the Burden of Proof}

In countries where massive human riglits violations continue, governments are already violating international law. Torture, arbitrary detention, extrajudicial killings, and disappearances are all violations of the Universal Declaration of Human Rights, ${ }^{316}$ other international and regional Conventions, ${ }^{317}$ and-at least in the case of torture, extrajudicial killings, or disappearances-customary law. ${ }^{318}$ It might be argued, therefore, that adding yet another violation to this hist-governmental noncomphance with an obligation to prosecute-is irrelevant. If governments are not responding to international condemnation for the abuses themselves, why should they be expected to be any more responsive to commandments to investigate these abuses?

316. See supra note 17 and accompanying text.

317. See supra notes $16,18-20$ and accompanying text.

318. See supra note 21 and accompanying text. 
There is, however, a reason to insist on an independent obligation to investigate and prosecute. The most recent waves of massive human rights violations imvolving disappearances and "death squad" killings are designed to conceal as far as possible any official involvement. As discussed above, ${ }^{319}$ it may be very difficult to establish the names or official positions of the perpetrators or to prove tlrat the state was involved at all.

An international obligation to investigate and prosecute shifts the burden of proof to the state to find out who is responsible and bring the appropriate parties to justice. Frequently the state alone has access to this information, yet in past international proceedings states liave often claimed ignorance and demanded that the coinplaining party produce evidence firmly establishing the violation. After imposition of the obhigation on states to investigate and prosecute, states inay no longer stand silent or fail to take action. Failure to fulfill this obligation places a state in a vulnerable international position, and thus removes part of the incentive to einploy illegal methods in the first place.

Salutary policy consequences follow from this shift in the burden of proof. If a state wishes to avoid embarrassing international condemnation and litigation, it inust provide meaningful opportunities for redress through its own judicial system. Any such action will strengthen the independence of the judiciary and provide external support to those judges worried about antagonizing the security forces. It inay also strengthen the hand of weak civilian governments fearing reaction from the still-powerful military. ${ }^{320}$

In practice, this means that international bodies like the Uuited Nations and regional Human Rights Commissions should not look merely to a decrease in current human rights violations to evaluate a country's performance, but also to the country's record in dealing with past violations. In the United States, it ineans tliat pledges by governments to investigate are not enough: the results of those investigations must weigh heavily in determining a country's eligibility for foreign assistance. $^{321}$

319. See supra notes 9-29 and accompanying text

320. An example is Guatemala, where a weak civilian government took over in 1985 from a military widely condemned for committing massive human rights violations. The military relinquished the government in large part from a desire to lessen the country's international isolation (and to obtain foreign aid), but they retain a veto over human rights policy and lave allowed no investigation of either past or current abuses. See AW, MUTUAL SUPPORT, supra note 178. An international obligation to investigate human rights violations, enforced in international forums by continued condemnation of the government, would give a reform-minded civilian government a lever witl which to push for reform of the armed forces' role.

321. By law, the United States cannot provide military aid or development assistance to countries whose governments violate liuman rights. See 22 U.S.C. § 2304 (1988). In recent years, Congress has conditioned aid to Guateniala on progress in achieving control over the military and in denıonstrating a deeline in violations compared to previous years. The result has been iucreased 
One potential difficulty with obligating states to prosecute past violators is that repressive rulers may be less willing to give up power if they beheve they will be subject to future investigation and prosecution. Promises of lemency after investigation and disciphinary or penal condemnation may be necessary to encourage certain of these rulers to step down. ${ }^{322}$ However, the deterrent effects of enforcing a duty to investigate and prosecute grave violations may outweigh this concern. If repressive rulers and their associates know they will be prosecuted for human rights abuses, they may be less willing to coinmit or tolerate such abuses in the first place. ${ }^{323}$ Further, repressive rulers rarely choose to give up power in any case: they are usually forced out by popular revulsion, international pressure, military coups, guerrilla armies, or some combination thereof. Thus, the additional disincentive to surrender power will have hittle practical effect.

\section{B. Implications for Democratic Governments Replacing Repressive Regimes}

Where less repressive, elected governments have replaced repressive regimes, the question becoines one of the present government's responsibility for prosecuting past huinan rights violations, rather than concern about continuing violations. In this situation, there are strong policy reasons for requiring the new government to investigate and prosecute those responsible for past violations. There are, however, also strong reasons that the new government inay be reluctant to prosecute.

The need for investigation is strong. Investigation of past violations is essential to provide victims' families with some relief, especially in cases of disappearance where the victim's fate may still be unknown. Furthermore, investigations will establish the new government's commitment to the rule of law, and will ensure that the inilitary or other forces responsible for past violations cannot present exculpatory versions of past events. ${ }^{324}$ Finally, investigation allows the "air to be cleared" of the

U.S. aid coupled with continuing violations. See Broder \& Lambek, Military Aid to Guatemala: The Failure of U.S. Human Rights Legislation, 13 YALE J. INT'L L. 111, 113 (1988). The proposal advanced in this Comment would tie aid to investigation and prosecution of past violations as well as ending current ones. The United States has already tied sone aid to prosecution of past violations. See supra notes 261-63 and accompanying text.

322. There is quite a difference, however, between leunency after a conviction (in sentencing or fines) and coniplete impunity. See Zalaquett, supra note 231, at 23.

323. The U.N. Rapporteur's report stresses the deterrent value of future prosecution: "The inost effective deterrent to the use of tortnre is the knowledge on the part of torturers that they unay one day be required to account for their actions." Study on Amnesty Laws, supra note 200, at 19.

324. Zalaquett, supra note 231, at 37-38. The military in Latin America have usually justified their abuses as necessary evils in the battle against world coninunism and for national security. Public exposure and condenınation of these abuses would lielp disabuse young officers and recruits of the idea that repression is a tolerable-even honorable-method of protecting the country. 
rumors, fear, and mutual suspicion created by years of repression, so that the country may move forward on a firm footing. ${ }^{325}$

The arguments for obligatory prosecution and punishment are similar to those for investigation. Purishment, while it cannot bring back the victims to their families, can provide the families with a measure of satisfaction. More importantly, it can serve a deterrent function. Those punished will be less inclined to repeat the abuses, and in the future others will be reluctant to risk pumshment by committing similar abuses. Public trials can demystify the dictatorship, exposimg the pettiness and incompetence of the former rulers as well as their brutality, "destroy[ing] withm seconds the military image of the strong man." ${ }^{326}$ Finally, it can estabhish the new government's ascendancy over the former military rulers, restore faith in the rule of law which nay have been severely damaged by years of dictatorship, and channel feelings of personal vengeance for the perpetrators of hunian rights offenses into more socially acceptable channels. ${ }^{327}$

As discussed above, ${ }^{328}$ punishment need not take the form of incarceration. Investigation itself, and disclosure of the identities of those involved, can be a form of punishinent. ${ }^{329}$ So too can loss of rank, dismissal from a government post, loss of pension rights and monetary fines. Fines collected from the violators could be used im part as monetary reparations for the victims and their families; this would be fairer than paying conipensation entirely from state funds and requiring taxpayers to shoulder the entire burden. ${ }^{330}$

325. See Weschler (pt. 2), supra note 44, Apr. 10, 1989, at 94.

326. Psomiades, supra note 233, at 264 (referring to the Greek trials of 1975-76).

327. Jaime Malamud-Goti, advisor to Argentine President Alfonsin during his first years in office, defined five consequences of criminal indictments and convictions:

1) ascertainment of concrete, tangible facts about misconduct;

2) institutional disapproval of official policies that resulted in the violation of human riglits, underlining the discontinuity between the new government and the old;

3) promotion of general confidence in equality of all citizens before the law;

4) restoring citizens to full meinbership in society by suppressing the differences between those who had control over other persons' lives and those whose existence was at their mercy. Malamud-Goti calls this the "expressive" or communicative function of punishinent, especially important in the case of state crimes to a) withdraw citizen support for liypothetical future dictatorships, and b) restore citizens' dignity after years of fear based on defenselessness of the citizenry faced with a state campaign of terror; systern.

5) improved chances for the military as an institution to adapt to the democratic

Malamud-Goti, Trying Violators of Human Rights: The Dilemma of Transitional Democratic Governments, in STATE CRIMES, supra note 231, at 71, 81-84.

328. See supra text accompanying note 183.

329. In addition to exposing those so identified to public opprobrium, investigation remedies the anguish of victims and their families. See supra text accompanying note 175.

330. See supra notes 159-83 and accompanying text (on possible remedies). Malamud-Goti argues for sanctions leveled at the military as an institution, because tlie institutional structure itself fosters criminality. Individual sanctions that do not cliange the institutional environment, lie argues, will be ineffective in the long run. Malamud-Goti, supra note 327, at 80-81. 
On the other hand, the violators will not submit voluntarily to investigation and punishment. This poses a dilemma for newly democratic governments and for human rights advocates. In many cases the new government is fragile and governs at the will of the military. ${ }^{331}$ Under these circunistances, moving to punish hunian rights violators may result in prolonged political imstability or even lead to a return to dictatorship, and thus may be counterproductive.

Proponents of amnesty assert that it is possible to move forward without an examination of the past, and that old hatreds should not be brought up again. Vice-President Tarigo of Uruguay, for example, argued that, as in post-Franco Spain, reopening of old wounds was best avoided to avert another civil war. ${ }^{332}$

Argentma provides the clearest example of a society grappling with these problems. The original indictments of military officers nunibered in the hundreds. ${ }^{333}$ But the trials moved slowly, and popular support for them eroded while the military closed ranks..$^{334}$ As military uprisings and mutimies increased, the government decided to limit the number of prosecutions. ${ }^{335}$ Those who defended the limitations on prosecution believed that deterrent and communicative functions could best be served by prosecuting only the highest-ranking officers, ${ }^{336}$ thus separating those most involved in abuses from the less compromised inajority of officers. They thought that wider prosecutions were untenable both because of their sheer scope and because junior officers had realistically had little chance to dissent from repressive policies. ${ }^{337}$ They also argued that more vigorous prosecution would surely lead to a military coup. ${ }^{338}$ Finally, they wished to avoid long delays caused by insufficient numbers of prosecutors and courts, ${ }^{339}$ and to focus public attention on a few cases.

331. See Broder \& Lambek, supra note 321, at 136-38 (Guatemalan civilian president wields little real power); see also discussion of Argentina and military reaction to trials, supra notes $30-43$ and accompanying text.

332. Wescliler (pt. 2), supra note 44, Apr. 10, 1989, at 92-93. Tarigo's analogy is a bad one, since the Spanisl Civil War was just that: both sides held territory and fielded armies. The Uruguayan experience, however, and that of most other Latin American countries, was far closer to a campaign by the military and security forces against civilians merely suspected of having radical ideas or affiliations. See Berman \& Clark, supra note 7, at 532-33.

333. See supra text accompanying note 37 .

334. See supra text accompanying note 38.

335. See supra text accompanying notes 39-42.

336. Osiel, supra note 29, at 151-53; see also Malamud-Goti, supra note 327, at 71-72.

337. Malamud-Goti, Transitional Governments in the Breach: Why Punish State Criminals?, 12 HUM. RTS. Q. 1, 3 (1990) [hereinafter Transitional Governments] (an updated version of MalamudGoti, supra note 327$)$.

338. See Malamud-Goti, supra note 327, at 74; Mignone, Estlund \& Issacharoff, supra note 37, at 149.

339. Malamud-Goti, supra note 327, at 73. Conceivably, these difficulties could have been lessened tlirough increased judiciary and staff; lowever, in countries with few resources and few lawyers, this may be unrealistic. Where countries have solved these problems by using unorthodox 
In contrast, human rights activists have criticized the amnesties and the Argentine decision to limit the initial prosecutions as well as its later "full stop" law. ${ }^{340}$ By trying to appease the military with half-measures, these critics argue, the civilian government lost the chance to inipose its authority and thus actually encouraged the subsequent displays of military force. ${ }^{341}$ They contend that selective prosecution of only the top twelve military officers, far from dividing the ranks of the military, served to give the military time to close ranks as an institution and push for ever-mcreasing numbers of concessions from the civilian government. $^{342}$ Concentrating on only twelve officers also led the population to take the trials less seriously than if the top sixty or one hundred officers had been tried. ${ }^{343}$

Part of the debate steins from the difficulty in deciding what amount of responsibility for the offense is necessary before the individual is held hable. ${ }^{344}$ Who should be punished: direct perpetrators, those who gave

tribunals in order to be able to try large numbers of people quickly, they have been severely criticized for not affording due process to defendants. See LAWYERS COMM. FOR INT'L HuM. RTS., Nicaragua: Revolutionary Justice 8-9 (1985) (Popular Anti-Somocista Tribunals did not provide adequate guarantees for defendants).

340. See Mignone, Estlund \& Issacharoff, supra note 37; M. SANCINETTI, supra note 255; AW, ARGENTINA, supra note 30; supra text accompanying note 39.

341. See Mendez \& Brown, Amnesty Laws in the Southern Cone: Argentina, Uruguay, Chile, Human Rights Watch, Dec. 1989, at 3. In the Philippines, the Aqumo government initially set up a Presidential Committee on Human Rights to investigate past abuses, but internal and external problems beset the Committee, and it eventually disbanded. The opportunity to begin effective prosecutions probably only existed during the six months after Aquino took office, when it would have capitalized on her popularity and absolute powers; after that the military was too strong to permit any action. Jones, Will to Prosecute Past Offenders Lost in the Philippines, Human Rights Watch (Dec. 1989), at 4. Study on Amnesty Laws, supra note 200, at 15, points out that "an amnesty covering persons guilty of conduct involving a serious infringement of human dignity (officials responsible for the use of torture as an administrative practice, persons guilty of crimes against humauity ... .), far from encouraging national rcconciliation, would only increase tension, at least initially."

342. See Henkin, Conference Report, in STATE CRIMES supra note 231, at 9. In Greece, in contrast, a similar initial strategy did manage to separate the bulk of the active-duty officer corps from the few leaders of the repression. Psomiades, supra note 233, at 264. Perhaps the difference hies in the nuuch more pervasive nature of repression in Argentina, in which the entire officer class was imvolved to one extent or another.

In Guatemala also, President Cerezo's refusal to take advantage of an initial popular mandate to investigate and prosecute the army has resulted in a growing list of army demands. The army is widely believed to be responsible for Cerezo's hard-line attitude towards the families of the disappeared. See generally AW, MUTUAL SUPPORT, supra note 178 (discussing the travails of families seeking “disappeared" members). Following a coup attempt in May 1988, Cerezo complied with army deniands to remove Interior Minister Juan Jose Rodil, who had proposed reforming the security forces. Cerezo also ended negotiations with the armed left, as the army had demanded. See generally AW, GUATEMALA, supra note 5 (discussing the Guatemalan political situation in the wake of the May 1988 coup).

343. Malamud-Goti, Transitional Governments, supra note 337, at 5.

344. The Nuremberg Principles, supra note 58, the Torture Convention, supra note 62, and the Genocide Convention, supra note 87, all make it clear that for certain aggravated offenses, following superior orders is not a legal defense. Argentina rccoguized this by exeinpting atrocious and 
the orders, or both? In most cases of massive human rights violations, almost all members of the security forces were involved to some degree with the repressive apparatus, whether as protagonists or as passive observers who did nothing to report or stop the commission of crimes. ${ }^{345}$ Human rights advocates argue that protecting junior officers from criminal responsibility while prosecuting the top officers allows those who directly participated in grave violations to emerge as the new leadership of the armed forces. These new leaders, moreover, emerge convinced that any civilian government lacks the will to control human rights violations by the military. ${ }^{346} \mathrm{~A}$ different strategy would be to punish as nuany offenders as possible, while differentiating degrees of responsibility through differing kinds and degrees of punishinent.

On the other hand, the Salvadoran experience exemplifies the opposite danger: prosecution of lower-ranking officers and soldiers may be used to justify the failure to prosecute commanding officers, using scapegoats and leaving untouched the decisionmaking hierarchy. In El Salvador, soldiers and lower-ranking officers have been accused of several killings, but higher-ranked officers have not been named despite evidence that the Army High Command ordered the killings. ${ }^{347}$

Thus, there are both practical and pohicy problems in imposing a duty to investigate and prosecute grave human rights abuses. However, experiences to date indicate that a well-desigued strategy of prosecution inay help to consolidate the rule of law, limit the military's authority, and provide some satisfaction for victims. Such a strategy should seek to reward cooperation by less culpable military officers (perhaps by shorter sentences or retention of benefits). It should be implemented as quickly as possible to maximize public and political support, ${ }^{348}$ and should attempt as far as possible to consolidate cases and evidence so as to reduce the burden on the judiciary.

\section{CONCLUSION}

This Comment has traced the evolution of an international duty of investigation by the state of grave human rights violations, and judicial or disciplinary action against those responsible. It has argued that such a norin is especially necessary now in view of the increased use of new

aberrant acts from its first due obedience law. See supra text accompanying note 33. However, the legal standard does not answer the policy question of which way is the best means of reestablishing the rule of law and avoiding similar institutional behavior in the future.

345. Malamud-Goti, Transitional Governments, supra note 337, at 3.

346. Mignone, Estlund \& Issacharoff, supra note 37, at 150.

347. See S.F. Examiner, Feb. 6, 1990, at 1, col. 4.

348. Even Malamud-Goti, one of then-President Alfonsin's advisers, now recognizes that the government should have moved more quickly before economic and social problems weakened the new administration. See Malamud-Goti, Transitional Governments, supra note 337, at 4-5. 
repressive methods, such as disappearances and death squad killings, designed to hide all evidence and allow the state to deny responsibility. The Comment has examined the experiences of several Latin American countries now grappling with this issue, and the related question of their error in granting amnesty to some or all of the perpetrators of these abuses. Finally, the Comment has introduced some of the policy and moral implications raised by enforcement of the norm.

Requiring states to imvestigate and prosecute the gravest human rights violations committed in their territory pulls together some of the thormiest strands of current human rights law. On the one hand, although international law recognizes that states do commit crimes, it is unclear what reinedies other states have against the state that does so. Regional human rights courts, such as the Inter-American Court, inay play the major role in making clear that a state's international obligation in these cases requires engaging doinestic legal and investigative institutions and, if necessary, reforming the military and security forces.

On the other hand, international law at this stage of development is inostly enforced by doinestic institutions; there is no international criminal court to try individual violators. By requiring a state to investigate and prosecute individual offenders or else face hability under imternational law, it is possible to link the concepts of a state's international responsibility for violations and individuals' responsibilities under international and domestic law. Thus, international law becoines more enforceable as it is apphed through domestic institutions. And human rights activists in each country acquire a powerful tool with which to press for improveinents in their country's human rights performance. 
